\title{
International Jurisprudence
}

\section{The Right of Public Access to Legal Information: A Proposal for its Universal Recognition as a Human Right}

\author{
By Leesi Ebenezer Mitee*
}

\begin{abstract}
This Article examines the desirability of the universal recognition of the right of public access to legal information as a human right and therefore as part of a legal framework for improving national and global access to legal information. It discusses the right of public access to legal information as a legal right and the importance of its international human rights framework. The Article argues that every person has the right of public access to legal information, which casts a legal and moral duty on every government and every intergovernmental organization (IGO) with judicial and legislative functions to provide adequate and free access to its laws and law-related publications. It argues further that every government can afford the provision of adequate public access to its legal information and that the lack of political will to do so is the preeminent factor responsible for inadequate-and in some cases extremely poor-public access. Additionally, this Article advocates the universal recognition of the right of public access to legal information as a human right and makes a proposal for a UN Convention on the Right of Public Access to Legal Information. It provides the essential contents of the proposed UN Convention which incorporate The Hague Conference Guiding Principles to be Considered in Developing a Future Instrument. These contents provide valuable input for urgent interim national and regional laws and policies on public access to legal information, pending the Convention's entry into force. The proposed UN Convention will significantly enhance global access to official legal information that will promote widespread knowledge of the law. It will also facilitate national and transnational legal research and remedy the chronic injustice from liability under inaccessible laws under the doctrine of "ignorance of the law is no excuse" which is similar to liability under ex post facto and nonexistent laws-and promote the proposed doctrine of "ignorance of inaccessible law is an excuse."
\end{abstract}

\footnotetext{
* Leesi Ebenezer Mitee, HND Town Planning and LLB (Rivers State University, Nigeria); BL (Nigerian Law School, Lagos); LLM (University of Huddersfield, United Kingdom); PhD Candidate, Tilburg University Law School, The Netherlands; Chief Lecturer in Law, Institute of Legal and Global Studies, Port Harcourt Polytechnic, Rivers State, Nigeria. I thank, immensely, the following persons for their most valuable insightful comments on the draft of this Article: Prof. Dr. Ernst M. H. Hirsch Ballin, Tilburg University and University of Amsterdam / Asser Institute, The Netherlands; and Dr. Sofia Ranchordás, Assistant Professor of Constitutional and Administrative Law at Leiden Law School, The Netherlands and Affiliated Fellow of the Yale Information Society Project, United States. Any error is mine. Email: leesimitee@leesimitee.com
} 


\section{A. Introduction}

Inadequacies in the existing system of providing public access to legal information cause difficulties in knowing the law, and these difficulties have profound adverse implications for justice, democracy, law reform, legal scholarship, sustainable development, legal practice, the rule of law, etc. ${ }^{1}$ For instance, injustice occurs whenever the doctrine which states that "ignorance of the law is no excuse" ${ }^{2}$ to avoid prosecution or culpability (hereinafter "ignorantia juris doctrine") is applied on the ground that every person is presumed to know the law, even when the law is inaccessible and therefore unknowable. That is what happened in the old case of Rex v. Bailey, ${ }^{3}$ and more recently in United States v. Casson. ${ }^{4}$ Close to 200 years ago, Jeremy Bentham scathingly likened this injustice to that of a tyrant and slaveholders. ${ }^{5}$ Additionally, difficulties in knowing the law-on the part of judges and lawyers-cause injustice through wrong judicial decisions. In Regina v. Chambers, it was a last-minute discovery "by a fortunate accident" that prevented the England and Wales Court of Appeal from delivering yet another wrong judgment due to ignorance of inaccessible law. ${ }^{6}$ The discovery led the Crown Prosecution Service to review previous cases of more than 2,615 affected defendants from 2001 to 2008 , some of whom successfully appealed their confiscation orders. ${ }^{7}$

\footnotetext{
${ }^{1}$ See discussions infra Section D.II.5 (discussing the remedy for the injustice from the ignorantia juris doctrine); Section D.II.6 (discussing the numerous benefits from adequate public access to legal information); Section D.II.8 (discussing the global promotion of the rule of law).

${ }^{2}$ The Latin maxim is ignorantia juris non excusat ("ignorance of the law is no excuse") or ignorantia juris neminem excusat ("ignorance of the law excuses no one").

${ }^{3}$ Rex v. Bailey (1800) 168 Eng. Rep. 651 (Eng.) (holding that a sailor at sea who had no way of knowing of a new law was guilty under it).

${ }^{4}$ United States v. Casson, 434 F.2d 415 (D.C. Cir. 1970) (holding that an amending legislation enacted just about six hours before the accused person committed a federal crime was applicable to him, even though it was obvious that people could not have known of the existence of the law and its contents within such a short period).

5 JeRemy Bentham \& John Bowring, The Works Of Jeremy Bentham 547 (1843); see Erwin N. Griswold, Government in Ignorance of the Law-A Plea for Better Publication of Executive Legislation, 48 HARV. L. REV. 198 (1934) (discussing inaccessibility of regulations in the light of Bentham's quote on the injustice in liability for contravening them).

6 Regina v. Chambers [2008] EWCA (Crim) 2467 [55]-[76] (UK), http://www.bailii.org/ew/cases/EWCA/Crim/2008/2467.html (revealing that previous decisions of the England and Wales Court of Appeal over a period of seven years were based on a repealed regulation that neither the Court nor the lawyers that appeared before it knew of).

7 See Chambers Review: Review of Confiscation Orders in Tobacco Cases, The Crown ProseCution SeRv., http://cps.gov.uk/publications/others/chambers_review.html (last visited July 6, 2017) [hereinafter Chambers Review].
} 
Inadequate-and in some cases extremely poor-public access to legal information is a prevalent problem in both developed and developing countries, but it is worse in the latter. ${ }^{8}$ The preeminent factor responsible for this problem appears to be the lack of political will on the part of governments to provide the legal framework, policies, facilities, programs, and institutions that are necessary to enable people to know the laws that regulate their conduct and activities. ${ }^{9}$ Therefore, any effective solution should be able to compel governmentswithin the limits of international law - to provide free access to comprehensive and up-todate legal information as a legal and moral duty. This should be part of a global mechanism for the promotion, realization, and protection of the people's right to know the law that they are bound to obey.

The existing literature on the right of public access to legal information as a human right consists of: (1) Merely stating that it is a human right without supporting the claim with arguments; (2) attempts to derive it from existing human rights and legal principles, some of which are remote; and (3) discussion of some aspects of the implications of lack of free access to legislation, which is just one category of legal information. ${ }^{10}$ There is likely no substantial discussion on why it should be formally recognized as a human right and the proper legal framework under which it can thrive as successfully as the established human rights. These gaps may explain why there appears to be no existing formal proposal for its universal recognition as a human right.

Therefore, to fill the said gaps in the existing literature, this Article aims to examine the desirability of the universal recognition of the right of public access to legal information as a human right and therefore as part of a legal framework for improving national and global public access to legal information. To achieve this aim, the following specific objectives shall guide this research: (1) To find out if there is an existing right of public access to legal information; and (2) To determine whether the right of public access to legal information, if it is found to exist, qualifies for universal recognition as a human right, which will strengthen it to improve national and global access to legal information.

The scope of the discussion is limited to public access to legal information for the benefit of all persons-irrespective of their profession and other circumstances ${ }^{11}$ - that is provided by every government and every intergovernmental organization (IGO) with legislative and judicial functions. Accordingly, I define "public access to legal information" as:

\footnotetext{
${ }^{8}$ See discussion infra Part B (arguing that a lack of political will hinders public access to legal information).

${ }^{9}$ See id.

${ }^{10}$ See discussion infra Part D.I (discussing the existing literature on the right of public access to legal information as a human right).

${ }^{11}$ For example, persons with disabilities need alternate legal information formats. See discussion infra Section D.III.2.11 (discussing the alternate formats for equal access by persons with disabilities).
} 
The opportunities and facilities provided by any government or intergovernmental organization (IGO) that enable people-in their different circumstancesto know the full, up-to-date texts of the whole stock of its laws and law-related publications, which guarantee the availability and free use of all formats online and in public libraries, without copyright in their texts nor in their official value-added features produced by the government or IGO either directly or under any arrangement with a third party. ${ }^{12}$

Commercial access to legal information is a profit-oriented service provided by private companies like LexisNexis and WestLaw. The success and prominence of the legal resources of those companies-despite any value-added features they contain-is one of the general indicators of inadequate public access to legal information, even in the developed countries.

This Article contributes to the literature on access to legal information and human rights law in several ways. First, it defines the right of public access to legal information and advances several reasons to prove its existence. Second, it argues extensively that the existing right of public access to legal information qualifies for recognition as a distinct human right, and makes a proposal for its formal universal recognition as such. Third, it goes further to advocate the making and adoption of a new UN Convention on the Right of Public Access to Legal Information and argues that the Convention will significantly improve global access to authentic $^{13}$ and official ${ }^{14}$ legal information. It also discusses the essential contents of the proposed UN Convention as a useful guide to its drafting. Among other numerous benefits, the proposed UN Convention will promote knowledge of the law, facilitate national and

\footnotetext{
${ }^{12}$ For an explanation of the elements in this definition, see discussion infra Part C (defining the "right of public access to legal information").

${ }^{13}$ See Am. Ass'n of LaW Libr., State-By-State Report on Authentication of Online Legal Resources: EXecutive Summary 2 (Mar. 2007), http://www.aallnet.org/Documents/GovernmentRelations/authen_rprt/executivesummaryreport.pdf ("An authentic text is one whose content has been verified by a government entity to be complete and unaltered when compared to the version approved or published by the content originator"). Authentication of digital legal information is vital to its integrity. See THE IALL INTERNATIONAL HANDBOOK OF LEGAL INFORMATION MANAGEMENT 14 (Richard A. Danner \& Jules Winterton eds., 2016); see also infra Section D.III.2.3 (discussing integrity and authoritativeness of legal information). See generally Claire M. Germain, Worldwide Access to Foreign Law: International \& National Developments Toward Digital Authentication 1-2 (University of Florida Levin College of Law Working Papers No. 1, 2012), http://scholarship.law.ufl.edu/cgi/viewcontent.cgi?article=1000\&context=working.

${ }^{14}$ See AM. Ass'N OF LAW LIBR., supra note 13 ("An official version of regulatory materials, statutes, session laws, or court opinions is one that has been governmentally mandated or approved by statute or rule. It might be produced by the government, but does not have to be").
} 
transnational legal research, and remedy the chronic injustice caused by the application of the ignorantia juris doctrine even when the law is inaccessible and therefore unknowable. Fourth, this Article reinforces the argument that it is the duty of every government to provide and guarantee free access to its comprehensive and up-to-date legal information. It also extends this duty to every non-State organization with legislative and judicial functions. Fifth, it proposes the defense of inaccessible law to directly negate the injustice in the slavish application of the ignorantia juris doctrine, and devises a new remedial, counterbalancing universal doctrine that "ignorance of inaccessible law is an excuse" in the appropriate circumstances.

The rest of this Article is structured in four Parts. Part B identifies the lack of political will as the major factor responsible for inadequate public access to legal information. Part $C$ examines the existence of the right of public access to legal information as a legal right. Part D makes a proposal for the formal universal recognition of the right of public access to legal information as a human right. It examines the existing literature and views on the right of public access to legal information as a human right, reveals the gaps in the discussions, and argues that the right should be formally recognized as a human right. Further, it discusses the proposal for the UN Convention on the Right of Public Access to Legal Information and outlines its essential contents which incorporate The Hague Conference Guiding Principles to be Considered in Developing a Future Instrument. Part E, the conclusion, integrates and synthesizes the key issues on the findings and proposals discussed in this Article and highlights the significance of the research and its policy relevance.

\section{B. Lack of Political Will Associated with Inadequate Public Access to Legal Information}

I had stated in a previous study that "[t]he political will of the state is of paramount importance for purposes of formulating appropriate policies that are conducive to implementation of public access to legislation projects." ${ }^{15}$ Every willing government can now provide adequate public access to its legal information by utilizing available and affordable information and communications technology (ICT). ${ }^{16}$ In this techno-centric age, publishing comprehensive and up-to-date legal information online with free access is indispensable and feasible. ${ }^{17}$ It is the most efficient and cost-effective way to enable people to access the laws

\footnotetext{
${ }^{15}$ Leesi Ebenezer Mitee, Public Access to Legislation and Its Inherent Human Rights: A Comparative Study of the United Kingdom and Nigeria (June 2006) (unpublished LLM dissertation, University of Huddersfield).

${ }^{16}$ For example, LexUM provides affordable industry-standard products and services for the management and dissemination of legal information. See Our Company, LEXUM, https://lexum.com/en/about-us (last visited July 6 , 2017).

17 See Daniel Poulin, Open Access to Law in Developing Countries, 9(12) FIRST MONDAY (2004), http://firstmonday.org/ojs/index.php/fm/article/view/1193/1113 (stating that "electronic distribution is the least expensive means of publishing" legal information and discussing its feasibility and the use of open source software); discussions infra Part B (arguing that lack of political will hinders public access to legal information); Section C.III (discussing the use of advanced technologies to enhance accessibility); Section D.III.2.1 (arguing that provision of
} 
that govern them, anytime and everywhere. ${ }^{18}$ In fact, there is already a movement towards digital-only legal information. ${ }^{19}$ That is why the availability of free, comprehensive, and upto-date official online legal information resources now constitutes the foremost benchmark of the adequacy of any public access to legal information program.

All it takes to provide at least the basic or starting-point free access to comprehensive and up-to-date legal information is digitizing - that is, converting the traditional printed version to its electronic format-and publishing it on dedicated official government websites. It will take just a couple of years to achieve this noble public service project. New legal information can be published online on the same day it is made, using its original electronic version to avoid reproduction errors. Even the native accessibility and navigational features of this basic online access make it far superior to the traditional print version of legal information. Every responsible government-that is worthy of the status of a government-should be able to afford the cost of providing this basic public access to legal information, which is an essential public service.

Therefore, it is the lack of political will ${ }^{20}$ that may explain why, for instance, some developing countries have extremely poor online access to their legal information. For example, neither the federal government of Nigeria-one of Africa's largest economies ${ }^{21}$-nor any of its thirty-six states has any official online legal information database. They only have insignificant fragments of primary legal resources here and there. ${ }^{22} \mathrm{~A}$ Canadian legal intern

free public access to legal information online is indispensable); see also Graham Greenleaf, Legal Information Institutes and the Free Access to Law Movement, Globalex (2008), http://www.nyulawglobal.org/globalex/Legal_Information_Institutes.html (stating that the World Wide Web provides "a low cost distribution mechanism" for free online access to legal information).

18 See Durham Statement on Open Access to Legal Scholarship of 2009 (Feb. 11, 2009), https://cyber.law.harvard.edu/publications/durhamstatement\#statement [hereinafter Durham Statement].

${ }^{19}$ See id.; discussion infra Section C.III (discussing the use of advanced technologies to enhance accessibility).

${ }^{20}$ See Henry H. Perritt, Jr. \& Christopher J. Lhulier, Information Access Rights Based on International Human Rights Law, 45 BufF. L. REV. 899, 900-01 (1997) (discussing the reluctance of some governments to provide electronic access to their legal information); Judith Bannister, Open Access to Legal Sources in Australasia: Current Debate on Crown Copyright and the Case of the Anthropomorphic Postbox, 3 JILT (1996), http://www2.warwick.ac.uk/fac/soc/law/elj/jilt/1996_3/bannister (discussing the importance of "the will and cooperation of the institutions which produce the primary sources"); Marc Masson \& Ovais Tahir, The Legal Information Needs of Civil Society in Zambia, 4 JOAL 18 (2016), https://ojs.law.cornell.edu/index.php/joal/article/view/45/61 (stating that the Zambian Government Printer officially responsible for publishing legal information explained that they could not publish its electronic version online because they lacked the statutory mandate to do so).

21 In 2014, Nigeria's US\$568,508 million Gross Domestic Product was ranked twenty-second in the world and number one in Africa, followed by South Africa and Egypt. See THE WORLD BANK, GROSS DOMESTIC PRODUCT 12014 , http://databank.worldbank.org/data/download/GDP.pdf.

${ }^{22}$ For example, the website of Nigeria's federal legislature, the National Assembly, contains only principal legislation made between 1999 and the present and Bills of the same period, yet Nigerian federal legislation in force spans a 
recently published an account of her frustration resulting from her inability to find Malian legal information she needed online. ${ }^{23}$ The lack of political will may also explain why the official online legal information databases of a rich and technologically advanced country like the United Kingdom do not appear to be comprehensive and up-to-date. ${ }^{24}$

Furthermore, this lack of political will also manifests in governments' assertion of copyright in legal information, despite the unimpeachable fact that every government holds such public information in trust for the people who are its rightful owners, ${ }^{25}$ and the people are entitled to know the laws that govern them. For instance, it is surprising that even in an advanced democracy like the United States, some state governments are enthusiastically asserting copyright in legal information through litigation. According to Carroll, "[s]ome states and municipalities in the United States assert copyright in their local legislation." 26 Some claim that the version of their official legislation containing annotations-which are meant to help the people to understand the law-are copyrightable. Their claim is absurd because the annotations in question constitute public information produced with taxpayers' money and therefore should be exempt from copyright the same way it is with any other U.S. public information. ${ }^{27}$ Any government that is interested in enabling its people to know the law should provide value-added features that will facilitate people's understanding of

long period of more than 100 years (1914-2016). See Fed. Republic of Nigeria NAT'L Assembly, http://www.nassnig.org/document/acts (last visited July 6, 2017). I had previously suggested that the reluctance of the Nigerian federal government to provide online access to its public information must have led to the late launch of its first website in 2005. See Mitee, supra note 15, at 102.

23 See Vallery Bayly, Legal Information and Human Rights, MCGILL UNIV. (July 31, 2015, 11:16 AM), http://blogs.mcgill.ca/humanrightsinterns/2015/07/31/legal-information-and-human-rights/.

${ }^{24}$ For express statements that the UK legislation online database is neither comprehensive nor up-to-date, see Help: Frequently Asked Questions (FAQs), LEGISLATION.GOV.UK, http://www.legislation.gov.uk/help\#aboutRevDate (last visited July 6, 2017); THE NAT'L ARCHIVES, GUIDE to REVISED LEGISLATION ON LEGISLATION.GOV.UK 6-7 (Oct. 2013), http://www.legislation.gov.uk/pdfs/GuideToRevisedLegislation_Oct_2013.pdf.

25 TISL Encouraged by Enactment of RTI in Sri Lanka, TRANSPARENCY INT'L SRI LANKA (July 11, 2016), http://www.tisrilanka.org/tisl-encouraged-by-enactment-of-rti-in-sri-lanka/; 3.1 - Information management and Access Laws for the 21st Century, OPEN Gov't PARTNERSHIP Australia (Oct. 10, 2017), https://ogpau.pmc.gov.au/commitment/31-information-management-and-access-laws-21st-century. See discussion infra Section C.I (discussing the existence of the right of public access to legal information under the general right of access to public or government-held information).

${ }^{26}$ Michael W. Carroll, The Movement for Open Access Law, 10 LEWIS \& CLARK L. REV. 741, 746 (2006) (discussing free access to legal information).

27 See Martha Neil, Georgia Sues Carl Malamud Group, Calls Publishing State's Annotated Code of Laws Online Unlawful, ABAJOURNAL.COM (July 24, 2015, 2:10 http://www.abajournal.com/news/article/State_of_Georgia_sues_Carl_Malamud_says_he_published_its_annota ted_code_of; Michael Hiltzik, Georgia Claims that Publishing its State Laws for Free Online is "Terrorism," L.A. TIMES (July 27, 2015, 12:31 PM), http://www.latimes.com/business/hiltzik/la-fi-mh-state-of-georgia-copyright-wall20150727-column.html. 
the law, such as annotations, summaries, indexes, and digests. Professional lawyers depend on such value-added features produced by commercial legal publishers-like LexisNexis and WestLaw - to know the law, for which they pay exorbitant periodic subscriptions. Therefore, non-lawyers-all those who have not acquired legal education that is comparable to that of lawyers-need such value-added features far more than lawyers need them.

In addition, the lack of political will extends to the policy of providing access to legal information as a revenue-generating enterprise instead of bearing the cost of doing so as an inherent cost of democracy. ${ }^{28}$ For example, some U.S. government agencies charge exorbitant fees for access to public records. ${ }^{29}$ Even the U.S. Public Access to Court Electronic Records (PACER) service provided by the Federal Judiciary ironically charges access fees for its so-called "public access" to online legal resources. ${ }^{30}$ Such a situation is profoundly detrimental to public access to legal information. That is the reason for Carl Malamud's famous fight against such non-compliant public access policies in the United States, which he started since 2007 when he established his nonprofit organization, Public.Resource.Org. ${ }^{31}$

It is simply unjust for governments to apply the ignorantia juris doctrine while deliberately denying the people their right of free access to the laws that they are legally bound to obey. Every government that has the political will to enable their people to know the laws that regulate their conduct and activities can achieve it, starting with the basic free online access to comprehensive and up-to-date legal information described above. Subsequent improvements to this basic access can be made using state-of-the-art technologies like the Tasmanian EnAct System. ${ }^{32}$ Every government should be willing to provide the opportunities and facilities to promote the public's knowledge of the law so as to avoid the grave injustice in the application of the ignorantia juris doctrine, even when the law is inaccessible and therefore unknowable. The people have the legal right to know the laws that they are bound

${ }^{28}$ See Tom McMahon, Improving Access to the Law in Canada with Digital Media, 16 GovernMENT INFORMATION IN CANADA (Mar. 1999), http://www.usask.ca/library/gic/16/mcmahon.html. Many governments monopolize the provision of access to legal information as a means of generating revenue. See Perritt, supra note 20, at 900-01.

${ }^{29}$ See Nick Grube, Many States Charge Insane Fees for Access to Public Records, Huffington Post (Oct. 17, 2013, 8:49 PM), http://www.huffingtonpost.com/2013/10/17/fees-for-public-records_n_4119049.html.

${ }^{30}$ See How Much Does PACER Cost?, PUB. ACCESS TO COURT ELEC. RECORDS, https://www.pacer.gov/ (last visited July 6 , 2017). For a campaign against PACER's fee-charging policy, see Jason Tashea, Carl Malamud's Crusade to Fix PACER, TECHNICAL.LY (Apr. 20, 2015, 11:14 AM), http://technical.ly/dc/2015/04/20/carl-malamud-pacer-dc-legal-hackersmeetup/.

${ }^{31}$ Public.ResourCE.ORG, https://public.resource.org/index.html (last visited July 6, 2017).

32 See The EnAct System, TASMANIAN LEGIS., http://www.thelaw.tas.gov.au/about/enact.w3p (last visited July 6, 2017); Timothy Arnold-Moore \& Jane Clemes, Connected to the Law: Tasmanian Legislation Using EnAct, JILT (2000), https://www2.warwick.ac.uk/fac/soc/law/elj/jilt/2000_1/arnold/. Legal information websites "may start small and simple" and progress to use "sound technology" for enhanced accessibility. See Poulin, supra note 17. 
to obey under the rule of law, ${ }^{33}$ which is the right of public access to legal information that I discuss in Part $\mathrm{C}$ below.

\section{The Existence of the Right of Public Access to Legal Information as a Legal Right}

Legal rights are entitlements defined, guaranteed, and protected by law. The definitive repositories of legal rights are the primary sources of law: Legislation or statute law, which includes constitutions; judicial decisions; regulations; administrative orders, directives, and rules; and binding regional and international legal instruments. These sources clearly define the respective rights so that they are capable of being identified and enforced. Legal rights are also found in binding customs, such as the customary law of indigenous peoples, which may be written or unwritten. Every legal right has a beneficiary or right holder who is entitled to it, the duty bearer who has the obligation to facilitate and guarantee its enjoyment, and the possibility and mechanism of its enforcement. ${ }^{34}$ I discuss all these aspects of the right of public access to legal information as a legal right in this Part. Because human rights are legal rights with an elevated status, the human rights aspect is examined in Part $D$ below.

I define the "right of public access to legal information" as:

The legal entitlement of all persons ${ }^{35}$-in their different circumstances - to know the full, up-to-date texts of the whole stock of the laws and law-related publications ${ }^{36}$ of

\footnotetext{
${ }^{33}$ See discussion infra Section D.II.8 (discussing global promotion of the rule of law).

${ }^{34}$ See Benny Santoso, "Just Business" - Is the Current Regulatory Framework an Adequate Solution to Human Rights Abuses by Transnational Corporations?, 18 GeRMAN L.J. 533, 540-41 (2017) ("Enforcement, including compensation, builds on jurisprudence that includes enforceability in the definition of legal rights."). For discussions of the concept of legal rights, see generally J. Raz, Legal Rights, 4 OXFORD J. LEGAL STUD. 1-21 (1984); Jules L. Coleman \& Jody Kraus, Rethinking the Theory of Legal Rights, 95 YALE L.J. 1335-72 (1986).

35 This term encompasses human beings who have attained the age of legal responsibility, and who have the capacity to read and understand the texts of the law, as well as corporate organizations.

36 "Laws and law-related publications" refers to primary legislation, secondary legislation, court decisions, international legal instruments, administrative memoranda, bills and other public documents directly related to the law-making function of the legislature (for example, debates and public hearings), reports on legal matters (for example, white papers and commissions of inquiry reports), and value-added publications that aid understanding and navigation of laws (for example, annotations, summaries, indexes, and digests). The oral or unwritten customary law of indigenous communities is inaccessible and unreliable. It should therefore be recorded in a written form in a manner-and through a process - that conforms to human rights and the specific rights of indigenous peoples. See discussion infra Section D.III.2.12 (discussing public access to the customary law of indigenous communities). For my discussion of my new concept of human rights-compliant public access to the customary law of indigenous communities, see Leesi Ebenezer Mitee, Huricompatisation: The Concept of Human Rights-Compliant Public Access to the Customary Law of Indigenous Communities (forthcoming 2017).
} 
their legislative jurisdiction, ${ }^{37}$ which guarantees the availability and free use of all formats online and in public libraries, without copyright in their texts nor in their official value-added features produced by any government or intergovernmental organization either directly or under any arrangement with a third party. ${ }^{38}$

I believe that this definition fulfills its objective of covering all the major aspects of the right of public access to legal information, and therefore the value of its comprehensiveness far outweighs the peripheral need for its conciseness. My aim is to provide a one-sentence quotable definition of the right of public access to legal information that is comprehensive. It should be emphasized that the term "public access," in this definition, means free online access on official legal information websites and free physical access in government-owned or public libraries. Both types of access should include all necessary alternate formats for persons with disabilities. ${ }^{39}$

\section{Its Existence Under the General Right of Access to Public or Government-Held Information}

Government-held information is public information that is owned by the people, and the government-as representatives of the people-holds such information in trust for them, as stated in Part B above. That is the reason for President Barack Obama's description of U.S. federal information as a "national asset" that must be open and transparent. ${ }^{40}$ The Declaration of Principles on Freedom of Expression in Africa by the African Commission on Human and Peoples' Rights states it aptly: "Public bodies hold information not for themselves but as custodians of the public good and everyone has a right to access this information ...." ${ }^{41}$ The Montreal Declaration on Free Access to Law (Montreal Declaration) made by the Free Access to Law Movement (FALM) also upholds this principle in relation to law by asserting that "[p]ublic legal information from all countries and international

\footnotetext{
37 “Legislative jurisdiction” refers to the geographical area under a particular legislature (national, state, or local).

${ }^{38}$ See supra notes 26-27 and accompanying text discussing the assertion of copyright in official annotations in legislation in the United States.

${ }^{39}$ See discussion infra Section D.III.2.11 (discussing alternate formats for equal access by persons with disabilities).

${ }^{40}$ Memorandum on Transparency and Open Gov't from Barack Obama, the President of the U.S., to the Heads of Exec. Dep'ts and Agencies (Jan. 21, 2009), https://www.whitehouse.gov/the_press_office/TransparencyandOpenGovernment https://www.whitehouse.gov/sites/default/files/omb/assets/memoranda_fy2009/m09-12.pdf.

${ }^{41}$ ACHPR/Res.62(XXXII)02, art. IV, para. 1, Declaration of Principles on Freedom of Expression in Africa (Oct. 23, 2002).
} 
institutions is part of the common heritage of humanity." ${ }^{42}$ Consequently, the people have an inherent right of public access to their information.

Laws on freedom of information are therefore based on this right of access to public information. Because legal information is an essential part of government-held or public information, ${ }^{43}$ the statutory existence of the right of public access to legal information can therefore be derived from laws containing provisions on the general right of access to public information. In Deaton v. Kidd, the Missouri Court of Appeals adopted the trial court's statement that "it is hard to think of a more important public record than the general laws of the state." ${ }^{44}$

Freedom of Information Acts (FOIAs) promote the right of access to public information. FOIAs-used here generally to refer to any substantial legislation wholly dedicated to freedom of information - provide broad access to some public documents and some private documents used by public bodies in accordance with data protection laws. ${ }^{45}$ Article 1 of Chapter 2 of the Swedish Freedom of the Press Act $1766^{46}$ (SFPA) is a significant contribution to the concept of free access to government-held information. The SFPA is acclaimed to be the world's oldest FOIA. ${ }^{47}$ At least 95 countries have FOIAs, according to the available statistics as of September 2013. ${ }^{48}$

As is the case with other types of public information, FOIAs may be used to compel the appropriate government department to grant any applicant access to legal information, as in Kidd..$^{49}$ But that is not the main use of FOIAs; ${ }^{50}$ their main use is reactive disclosure of other

\footnotetext{
${ }^{42}$ Free Access to Law Movement, Declaration on Free Access to Law of 2002, http://www.falm.info/declaration/ [hereinafter Montreal Declaration]; see also Greenleaf (2008), supra note 17 (discussing historical background to legal information institutes and the Free Access to Law Movement).

${ }^{43}$ See Mitee, supra note 15, at 168.

${ }^{44}$ Deaton v. Kidd, 932 S.W.2d 804, 806 (Mo. Ct. App. 1996)

${ }^{45}$ See, e.g., Freedom of Information Act 2000, c. 36, §§ 21-44 (UK) (the numerous types of exempt information that cannot be accessed under the Act).

${ }^{46}$ This Act is one of the four fundamental laws that comprise the Swedish Constitution. TRYCKFRIHETSFÖRORDNINGEN [TF] [CONSTITUTION] 2:1 (Swed.) (Dec. 16, 2016), http://www.riksdagen.se/en/How-the-Riksdagworks/Democracy/The-Constitution/.

47 Sweden: International Focus, UNIV. ColL. LONDON, https://www.ucl.ac.uk/constitutionunit/research/foi/countries/sweden (last visited July 6, 2017).

48 Access to Information Laws: Overview and Statutory Goals, RIGHT2INFO (Jan. 20, 2012), http://www.right2info.org/access-to-information-laws.

${ }^{49}$ Deaton, 932 S.W.2d. For the facts of this case, see infra text accompanying note 100.

${ }^{50}$ See McMahon, supra note 28 (limitations with using FOIAs to access legal information).
} 
categories of public information on request and on a piecemeal basis. FOIAs also encourage proactive disclosure-the provision of comprehensive accessibility in a ready and permanent form for the whole world, devoid of procedural conditions that include requests. ${ }^{51}$ But effective proactive publication of public information requires mandatory statutory provisions that make it the default publication method. Such provisions are not likely to be found in FOIAs. Therein lies the inadequacy of FOIAs to protect the right of public access to legal information.

Adequate public access to legal information requires its publication in both physical and electronic media to make it permanently available at all times for everybody. That type of availability eliminates the need for an individual request for any document containing legal information. Individual request is the dominant practice under FOIAs. Darbishire rightly identified such proactive publication or disclosure without the need for request, as the "future" of the right of access to public information..$^{52}$ It is significant that after more than four decades of the existence of the U.S. Freedom of Information Act-one of the oldest in the world-President Barack Obama issued a memorandum on the need for proactive disclosure ${ }^{53}$ the day after his inauguration as President of the United States. That presidential directive reveals the defect of inadequate proactive publication under FOIAs.

Some countries have realized the limitations of the traditional FOIAs, and they have gone further to enact legislation that specifically enhances the right of access to public information. For example, Bulgaria enacted its Access to Public Information Act 2000 (BAPIA). Article 23 of the Constitution of the Republic of Albania 1998 contains an express right to information in addition to freedom of information. But even these improved statutory provisions are not sufficient to cover the specific and technical aspects of an adequate public access to legal information program, including authentication of digital legal information. $^{54}$

\footnotetext{
${ }^{51}$ For the meaning of reactive and proactive disclosures, see Address by the Interim Information Commissioner of Canada on Proactive Disclosure Before the Standing Committee on Access to Information, Privacy and Ethics, OFFICE OF THE INFO. COMM'R OF CAN. (Apr. 29, 2010), http://www.oic-ci.gc.ca/eng/pa-ap-appearance-comparution2010_3.aspx.

${ }^{52}$ See generally Helen Darbishire, Proactive Transparency: The Future of the Right to Information? A Review of Standards, Challenges, and Opportunities, THE WORLD BANK (2011), http://siteresources.worldbank.org/EXTGOVACC/Resources/DarbishireProactiveTransparency.pdf; Publish Core Information about Government on a Proactive Basis, OPEN Gov'T GUIDE, http://www.opengovguide.com/commitments/publish-core-information-about-government-on-a-proactivebasis/ (last visited July 6, 2017).

53 Memorandum on the Freedom of Info. Act from President Barack Obama to the Heads of Exec. Dep'ts and Agencies (Jan. 21, 2009), https://www.whitehouse.gov/the-press-office/freedom-information-act.

${ }^{54}$ See supra note 13 (discussing authentication). For the specific and technical aspects of an adequate public access to legal information program, see discussion infra Section D.III.2 (discussing contents of the proposed UN Convention).
} 


\section{Its Existence Under the Traditional Requirement of Publication of Legal Information}

The traditional requirement that laws should be published so that the people whose conduct and activities they regulate are aware of their existence has been recognized since time immemorial. That recognition has remained intact down through the millennia. It was the reason behind the inscription of ancient laws on stones and other media and displaying them in public places. For instance, the Code of Hammurabi in the 18th century B.C. consisted of 282 laws $^{55}$ written on a basalt stele measuring 2.25 meters high and 0.65 meters wide. ${ }^{56}$

Section 4 of the New Zealand Acts and Regulations Publication Act 1989 (ARPA) is an example of the traditional requirement in national legislation to publish laws. It does not specify the medium for publication. From the long title of the ARPA, "to ensure that copies of Acts of Parliament and statutory regulations are available to the public" is one of its objectives. Section 5(1) of the Nigerian Acts Authentication Act 1962, a piece of federal legislation, is an example of obsolete provisions on publication of legal information. It mentions "vellum" 57 and "paper" as the only media for publication of legislation, using an outmoded printing technology. They were probably the available printing media in Nigeria at the time the legislation was enacted, more than five decades ago. The continued existence of such obsolete provisions is detrimental to public access to legal information in this information and communications technology (ICT) age when the electronic format has become not just an indispensable alternate medium, but sometimes the only one.

Article 14 of the UN Declaration on the Right and Responsibility of Individuals, Groups and Organs of Society to Promote and Protect Universally Recognized Human Rights and Fundamental Freedoms ${ }^{58}$ (UN Declaration on Human Rights Defenders) contains the requirement to publish legal information. It states: "The publication and widespread availability of national laws and regulations and of applicable basic international human rights instruments" is necessary for helping the people to understand "their civil, political, economic, social and cultural rights." Although this Declaration is non-binding, like similar declarations of the United Nations, responsible governments are expected to enforce its universal democratic principles as national policies.

\footnotetext{
${ }^{55}$ The Code of Hammurabi (L. W. King trans. 2008), YALE L. SCH., http://avalon.law.yale.edu/ancient/hamframe.asp (last visited July 6, 2017).

${ }^{56}$ Law Code of Hammurabi, King of Babylon, THE LOUVRE MUSEUM, http://www.louvre.fr/en/oeuvre-notices/lawcode-hammurabi-king-babylon (last visited July 6, 2017).

${ }^{57}$ See discussion infra Section D.III.2.4 (discussing preservation of legal information).

${ }^{58}$ G.A. Res. 53/144, UN Declaration on the Right and Responsibility of Individuals, Groups and Organs of Society to Promote and Protect Universally Recognized Human Rights and Fundamental Freedoms (Dec. 9, 1998) [hereinafter UN Declaration on Human Rights Defenders].
} 
Bare statutory provisions, such as those mentioned above, that only stipulate that laws should be published without mentioning the effects of their nonpublication are defective. Article IV, Section 17 of the Wisconsin Constitution contains such important provision: "No law shall be in force until published." A further improvement on this is found in Article 2 of the Civil Code of the Philippines: "Laws shall take effect after fifteen days following the completion of their publication in the Official Gazette, unless it is otherwise provided. This Code shall take effect one year after such publication." The Supreme Court of the Philippines enforced this provision in Tañada v. Tuvera. ${ }^{59}$

There is the need for law reform to enable every country to have provisions which expressly stipulate that laws only come into effect after their publication. It is important to emphasize that such provisions should apply to all categories of laws to avoid the situation in England and Canada where only subsidiary legislation-also referred to as regulations in some jurisdictions, e.g. the United States-appear to have such publication requirement. ${ }^{60}$ Nevertheless, justice may demand that any time-sensitive benefit that any person ought to have received under an unpublished law is protected, as recommended by the Statute Law Society. ${ }^{61}$

Despite its defects, one implication of the traditional requirement to publish the law is that the duty to provide public access to legal information precedes the duty of every person to know the law. Consequently, all persons have the right to know the full contents of any legal information that applies to them, which is only possible where there is adequate public access to the sources of such legal information. It is reiterated that this right is the basis for the presumption that every person knows the law, ${ }^{62}$ and therefore ignorance of the law is no excuse for its contravention. ${ }^{63}$

\footnotetext{
59 Tañada v. Tuvera, G.R. No. L-63915, 136 SCRA 27 (Apr. 24, 1985) (Phil.). See infra notes 99 \& 296 and accompanying text on the Court's requirement that laws must be published before they take effect.

${ }^{60}$ See, e.g., Statutory Instruments Act, R.S.C. 1985, c S-22 s 11 (Can.); Statutory Instruments Act 1946, 9 \& 10 Geo. 6 c. 36, § 3(2) (Eng.); Andrew Ashworth, Ignorance of the Criminal Law, and Duties to Avoid It, 74 MoD. L. Rev. 1, 2 (2011) (discussing some recognized exceptions to the doctrine of ignorance of the law is no excuse); Mitee, supra note 15 , at $38-39$.

${ }^{61}$ See Statute L. Soc'y, Statute Law Society Working Party on Commencement of Acts of Parliament, 1(1) STATUTE L. REV. 40, 51 (1980).

62 See JefFerson L. INGRAM, CRIMINAL EVIDENCE $\S 6.13$ (12th ed. 2015) (discussing the presumption of knowledge of the law). IOWA CODE $\S 701.6$ (2016) is an example of statutory provision that "[a]ll persons are presumed to know the law."

${ }^{63}$ See Blackpool Corporation v. Locker [1948] 1 KB 349, 361 (Eng.), in Bannister, supra note 20; Don STUART, CANADIAN CRIMInal LaW: A Treatise 295-98 (3d ed., 1995), in Corporation de l'École Polytechnique v. Canada, 2004 FCA 127, para. 37 (CanLII).
} 


\section{Its Existence Under the Requirement of Publication of Legal Information with Advanced Technologies to Enhance Accessibility}

As discussed in the immediately preceding Section C.II above, the traditional requirement for the publication of legal information cannot meet the demands of the twenty-first century that has been rightly described as the information technology or digital age. ${ }^{64}$ Lee Loevinger pioneered the revolutionary application of technology to law in the United States in $1948^{65}$ with his concept of jurimetrics in his seminal article published in $1949 .{ }^{66}$ The U.S. federal and state laws contain provisions for the use of advanced technologies that enhance accessibility of legal information. For example, provisions of the Oregon Revised Statutes state that legal information shall be published online, ${ }^{67}$ made available in alternate formats for diverse users, ${ }^{68}$ and that access to it shall be free. ${ }^{69}$ Although they are deficient in details and are not comprehensive, such improved provisions will enhance public access to legal information.

At the international level, there is a useful provision in Article 19(2) of the International Covenant on Civil and Political Rights (ICCPR) with respect to variety of media for publishing public information. Although the provision is not specific, it can be interpreted to cover every form of legal information, which is a major component of public information, as stated in Section C.I above. Article 5(3) of the UN Economic Commission for Europe (UNECE) Convention on Access to Information, Public Participation in Decision-Making and Access to Justice in Environmental Matters ${ }^{70}$ (Aarhus Convention) is an express provision for enhanced publication of legal information. The said Article 5(3) requires each Party to the Convention to ensure that every text of laws and appropriate policies, plans, and programs on or relating to the environment "progressively becomes available in electronic databases which are easily accessible to the public through public telecommunications networks."

\footnotetext{
${ }^{64}$ See Bin Yu, Embracing Statistical Challenges in the Information Technology Age, 49 TECHNOMETRICS 237, 237-38 (2007); Claire M. Germain, Legal Information Management in a Global and Digital Age: Revolution and Tradition 22-23 (Cornell Legal Studies Research Paper No. 07-005, 2007), http://ssrn.com/abstract=983197 or http://dx.doi.org/10.2139/ssrn.983197.

${ }^{65}$ See Layman E. Allen, Festschrift: Lee Loevinger, 40 JURIMETRICS 394, 394 (2000).

${ }^{66}$ See Lee Loevinger, Jurimetrics: The Next Step Forward, 33 MinN. L. REV. 455 (1949).

67 See OR. REV. STAT. § 173.763(2)(a) (2015).

${ }^{68}$ See id. $§ 173.763(2)$.

${ }^{69}$ See id. § 173.763(5).

70 UNECE Convention on Access to Information, Public Participation in Decision-Making and Access to Justice in Environmental Matters, June 25, 1998, 2161 U.N.T.S. 447; 38 ILM 517 (1999) [hereinafter Aarhus Convention].
} 
The basic technology that is freely available for publishing legal information involves merely uploading an electronic version to a website. Advanced technologies are also required for managing legal information and for achieving the overall goal of providing optimum access for different categories of users. For instance, specialized assistive technology is used to produce enhanced accessibility for persons with disabilities. The Federal Register of Legislation, the official legislation website of the Government of Australia, uses BrowseAloud assistive technology to enhance accessibility through text-to-speech and screen magnification for persons with literacy problems, cognitive disabilities, and visual impairment. ${ }^{71}$ Tasmania, an Australian state, uses the innovative EnAct Legislation systemwhich is one of the most advanced legislation management systems in the world-for drafting and management of legislation. ${ }^{72}$ Among other requirements, online legal information databases should have advanced search functionality that enhances accessibility by making it easy to discover every piece of relevant information.

There is now the tendency towards digital-only legal information-born-digital ${ }^{73}$ legal information without any print version-as advocated in the Durham Statement on Open Access to Legal Scholarship made by the directors of the law libraries of some U.S. universities in 2009. ${ }^{74}$ The digital-only revolution is now so pervasive that it has already created at least one digital-only bank with no branches or call centers ${ }^{75}$ and digital-only newspapers, including a national newspaper. ${ }^{76}$

Several organizations have made declarations and formulated principles and statements on the publication of primary legal information that contain ideas on its modern electronic format. They include the Montreal Declaration on Free Access to Law (2002), ${ }^{77}$ The Hague Conference Guiding Principles to be Considered in Developing a Future Instrument (2008), ${ }^{78}$

\footnotetext{
${ }^{71}$ Accessibility: Assistive Technology, FED. REG. OF LEGIS., https://www.legislation.gov.au/Content/Accessibility (last visited July 6, 2017); Listen to this Website with Browsealoud, FED. REG. OF LEGIS., https://www.legislation.gov.au/content/browsealoud (last visited July 6, 2017).

72 See supra note 32 (sources cited discussing the EnAct System).

${ }^{73}$ Born-digital information here refers to information that was created originally in electronic format, as opposed to information converted from its original print to an electronic format.

${ }^{74}$ Durham Statement, supra note 18.

75 Jill Treanor, Atom Becomes UK's First Digital-Only Bank, THE GUARDIAN (Apr. 8, 2016, 6:11 PM), http://www.theguardian.com/money/2016/apr/08/atom-first-uk-digital-only-bank.

${ }^{76}$ The Independent Becomes the First National Newspaper to Embrace a Global, Digital-Only Future, THE INDEPENDENT (Feb. 12, 2016, 1:24 PM), http://www.independent.co.uk/news/media/press/the-independent-becomes-the-firstnational-newspaper-to-embrace-a-global-digital-only-future-a6869736.html.

${ }_{77}$ Montreal Declaration, supra note 42.

78 The Hague Conference Guiding Principles to be Considered in Developing a Future Instrument (2008), an annexure to ACCESS TO FOREIGN LAW IN CIVIL AND COMMERCIAL MATTERS: CONCLUSIONS AND RECOMMENDATIONS, EUR. COMm'N,
} 
Law.Gov Principles and Declaration, ${ }^{79}$ and Calgary Statement on Free Access to Legal Information (2011). ${ }^{80}$

A modern law on public access to legal information should contain all the relevant standards and technical details on the application of technology for improving accessibility. Such technical information is usually confined to schedules or annexes to legislation. This is the standard practice in legislative drafting manuals, including those of the United Kingdom ${ }^{81}$ and the European Union. ${ }^{82}$ I did not find any law wholly dedicated to public access to legal information during my research for this Article. It is only such dedicated legislation that is likely to have comprehensive provisions and schedules or annexes on technical aspects of the subject matter.

\section{The Duty Bearers to Publish the Law Under the Existing Right of Public Access to Legal Information}

The beneficiaries of the right of public access to legal information are the people, corporate organizations, and organs of the government that are entitled to know the laws that regulate their conduct and activities. They include people all over the world because of the need for global legal research, migration, travel, and other transnational activities such as online business transactions and social interactions. This is particularly important because the application of the ignorantia juris doctrine extends to any unlawful act committed by a foreigner in another jurisdiction, even when that same act is lawful in the foreigner's home jurisdiction. ${ }^{83}$ Indeed, free access to comprehensive and up-to-date legal information from all countries and jurisdictions is essential.

https://assets.hcch.net/upload/foreignlaw_concl_e.pdf (last visited July 6, 2017) [hereinafter The Hague Conference Guiding Principles]. The Principles were developed by the experts who met on Oct. 19-21, 2008 at The Hague Conference on Private International Law.

79 Law.Gov, Law.Gov Principles and Declaration of 2010, https://law.resource.org/index.law.gov.html [hereinafter Law.Gov Principles].

${ }^{80}$ Council of Canadian Academic Law Library Directors, Calgary Statement on Free Access to Legal Info. of 2011, http://www.osgoode.yorku.ca/wp-content/uploads/2014/07/Calgary_Statement_2011-05-14.pdf [hereinafter Calgary Statement].

81 OfFice OF the Parlamentary Couns., Drafting Guidance 25 (June, 2017), https://www.gov.uk/government/uploads/system/uploads/attachment_data/file/454628/guidancebook_August _2015.pdf.

82 EUR-Lex, Joint Practical Guide for Persons Involved in the Drafting of European Union Legislation 74 (2015), http://eur-lex.europa.eu/content/techleg/KB0213228ENN.pdf.

${ }^{83}$ Mohammad v. State, 1953 AIR 227, para. 19 (PB) (India) (holding that "[i]gnorance of law by a foreigner may be no legal defence but it is a matter to be taken into consideration in the matter of mitigation of punishment"); Regina v. Barronet (1852) 169 Eng. Rep. 633 (QB) (Eng.) (rejecting the defense that acting as seconds to their friend who died in the duel was lawful in their home country, France, and they were not awa re that it was unlawful in Great Britain where they committed it); Regina v. Esop (1836) 173 Eng. Rep. 203 (Eng.) (rejecting the defense that 
Who, then, are the duty bearers that have the responsibility to provide public access to legal information for the benefit of these beneficiaries? Whoever originates or creates legal information has the duty to provide free access to its comprehensive and up-to-date sources. Consequently, every government bears this duty, ${ }^{84}$ as well as every IGO with legislative and judicial functions. This duty to publish the law precedes the duty of every person to know the law, upon which the presumption of knowledge of the law ${ }^{85}$ is based. That presumption is the foundation of the ignorantia juris doctrine. The courts have maintained that the purpose of publishing legal information is to protect the people against unknowable laws that jeopardize their rights and interests-a primary obligation of every government to its citizens and residents. ${ }^{86}$ I discuss the express judicial recognition and enforcement of this duty in Section C.V below.

To avoid the possibility of problems arising from the custodianship, copyright, and control of legal information and to reduce the cost of providing free access to it by the government, this duty should not be outsourced to commercial publishers. ${ }^{87} \mathrm{I}$ had stated previously that a "[g]overnment may contract aspects of the process to the private sector." 88 But no such contract should include any third-party copyright in nor control of any database, nor any arrangement that can jeopardize the complete control of the database by the government or IGO.

buggery, anal sexual intercourse, was lawful in his home country, Iraq, and he did not know it was unlawful under English law where he committed it).

${ }^{84}$ See Timothy J. Arnold-Moore, Point-In-Time Publication of Legislation (XML and Legis/ation): Automating Consolidation of Amendments to Legislation in Common Law and Civil Jurisdictions, Paper presented at the 6th Law Via the Internet Conference, Paris, Nov. 3-5, 2004, http://www.frlii.org/IMG/pdf/2004_frlii_conference_tja.pdf (discussing the duty of the government to provide free access to legal information and the indispensability of online databases to achieving it); see also Timothy Arnold-Moore, XML and Legis/ation, COMPLRES 29 (2003), http://www.austlii.edu.au/cgi-bin/sinodisp/au/other/CompLRes/2003/29.html; McMahon, supra note 28; Mitee, supra note 15, at 70 (stating that "every government is under both legal and moral obligations to provide adequate access to the full-text of every legislation that is applicable in its jurisdiction").

${ }^{85}$ See INGRAM, supra note 62.

${ }^{86}$ Milwaukee Journal Sentinel v. Wisconsin Dept. of Admin., 768 N.W.2d 700, 712-13 (2009).

87 For the accounts on how West Publishing ownership right in the JURIS database caused huge problems to the U.S. Department of Justice when it pulled out of JURIS and removed its data, see Beth Ford, Open Wide the Gates of Legal Access, 93 OR. L. Rev. 539, 546-49 (2014); Gary Wolf, Who Owns the Law?, WIRED (May 1, 1994), http://www.wired.com/1994/05/the-law/. Resources on Sri Lanka's official legal information website, see LAWNET, http://www.lawnet.lk/ (last visited July 6, 2017), developed with funding from the World Bank, have been inaccessible since the outsourcing private company went out of business more than six years ago. See Graham Greenleaf, Free Access to Legal Information, LIIs, and the Free Access to Law Movement, in IALL INTERNATIONAL HANDBOOK OF Legal Information ManAgement (Richard A. Danner \& Jules Winterton eds., 2011), http://ssrn.com/abstract=1960867.

${ }^{88}$ See Mitee, supra note 15 , at 95. 
Similarly, no government or IGO should depend on not-for-profit organizations to provide public access to its legal information. Unfortunately, some governments appear to do so to varying degrees. For example, the Law Reporting department of the Judiciary of Uganda publishes Ugandan legal information on the Uganda Legal Information Institute website. ${ }^{89}$ Further, such dependence is implied in the following statement on the UK Parliament website: "The archived House of Lords judgments are the only case law that Parliament holds. For any other court decision you will need to use a legal information service such as the British and Irish Legal Information Institute (BAILII), which is free to access." ${ }^{\prime 90}$ Although there are official online databases of the decisions of the UK courts, ${ }^{91}$ the statement can be interpreted to mean the BAILII database may be the only online repository of some decisions. The importance of the legal resources of BAILII and those of other legal information institutes and free access providers is limited by their lack of authenticity and official status, ${ }^{92}$ which denies them evidentiary value. The disclaimers on their websites reveal this defect. BAILII's disclaimer specifically states: "BAILII does not invite reliance upon, nor accept responsibility for, the information it provides. ${ }^{13}$ Yet it is such reliance that authentic legal research is based on.

Greenleaf, Mowbray, and Chung have advocated that third parties should play what appears to be a leading role in the provision of free public access to legal information. According to them,

The obligations of the State, in relation to all primary legal materials ('materials'), are to provide these materials to other parties to republish, without fee, in the most complete, authentic and authoritative form possible, and so that materials may be republished with their authority and integrity intact .... If necessary, the

\footnotetext{
${ }^{89}$ See Law Reporting, THE JUDICIARY OF UGANDA, http://www.judiciary.go.ug/data/smenu/25/Law\%20Reporting.html (last visited July 6, 2017).

90 See Judgments: Other Judgments, PARLIAMENT.UK, http://www.parliament.uk/about/how/business/judgments/ (last visited July 6, 2017). The British and Irish Legal Information Institute (BAILII) website (http://www.bailii.org/) contains vast resources on the UK legal information, including legislation and judgments. It is a non-profit organization and a member of the Free Access to Law Movement (http://www.fatlm.org/).

${ }^{91}$ See, e.g., Decided Cases, THE SUP. CT., https://www.supremecourt.uk/decided-cases/index.html (last visited July $6,2017)$.

${ }^{92}$ See supra note 13 (discussing the definition of authentic texts of legal information) \& note 14 (discussing the definition of official texts of legal information).

${ }^{93}$ Disclaimers of Liability, BRIT. \& IRISH LEGAL INFO. INST., http://www.bailii.org/bailii/disclaimers.html (last visited July 6, 2017).
} 
State should take the role of providing free access to these materials. ${ }^{94}$

The contribution of these distinguished scholars and experts to public access to online legal information worldwide is huge and highly commendable, but I am unable to agree with their above-quoted assertion on the obligations of the State. Their position is the same principle adopted by many free access providers, including the legal information institutes. ${ }^{95}$ How can any government abdicate this all-important primary public duty to third parties? It is always necessary in every circumstance that the State must perform its legal and moral obligation to provide free and adequate public access to its legal information-not "if necessary", as stated in the above quotation. The obligation of the State is to do so directly to the people, not exclusively "to other parties to republish", as also stated in the above quotation. All users of legal information-including third parties who republish it-have equal access to it, directly from the same official State source.

If the duty of the State is merely to make legal information available to third parties to republish, who will the people hold accountable if the third parties fail to provide adequate public access to such information after the State had done its part? Third parties cannot be held responsible because they have no such duty. I agree completely with Arnold-Moore who stated unequivocally that "the government has a clear obligation to make the primary legal sources available to the public." 96

Members of FALM-most of which are the legal information institutes-and other publishers of free legal information should see their invaluable contribution to free public access to online legal information as filling the gap created by the neglect of the duty bearers who have the legal obligation to do so. They should extend their free-access-to-law advocacy to putting pressure on the duty bearers to perform their obligation to provide free access to their comprehensive and up-to-date legal information. In addition, third-party, free-access publishers of online legal information should provide annotations and other value-added services that will help people to understand the law. This new direction will create a more beneficial synergy in their relationship with governments and IGOs that are duty-bound to provide free and adequate public access to their legal information. I predict that someday,

\footnotetext{
94 Graham Greenleaf, Andrew Mowbray \& Philip Chung, The Meaning of "Free Access to Legal Information": A Twenty Year Evolution, 1 JOAL (2013), https://ojs.law.cornell.edu/index.php/joal/article/view/11 (emphasis added).

${ }^{95}$ Legal information institutes are members of the Free Access to Law Movement (FALM), an international nonprofit association that provides and supports free access to legal information from different countries. See THE FREE ACCESS TO LAW MOVEMENT, http://www.fatlm.org/ (last visited July 6, 2017).

96 Arnold-Moore (2004), supra note 84 (discussing the duty of the government to provide free access to legal information and the indispensability of online databases to achieving it) (emphasis added); see also Arnold-Moore (2003), supra note 84; McMahon, supra note 28.
} 
in any legislative jurisdiction-national, state, and local-where its government has provided free online access to its comprehensive and up-to-date legal information on its dedicated one-stop website, that jurisdiction's third-party unofficial legal information databases that do not have value-added features will begin to lose their relevance.

From the foregoing analysis, the provision of free and adequate public access to its legal information is undeniably a primary duty of every government. Every IGO with legislative and judicial functions-examples of which include the United Nations, Organization of American States, European Union, African Union, Association of Southeast Asian Nations, and the Arab League-also has this duty with respect to the legal information it creates or originates.

\section{Judicial Recognition and Enforcement of the Existing Right of Public Access to Legal Information}

The courts have both recognized and enforced the right of public access to legal information that goes with the duty of the government to provide the required access. I mentioned at the beginning of this Part that capability of enforcement is one of the features of a legal right. The importance of the judicial recognition of the right of public access to legal information stems from the fact that case law is one of the sources of law in common-law legal systems. Case law is an authoritative source of binding legal principles, some of which are not found in legislation nor in any other source of law. It is one of the mechanisms that helps the courts to avoid arbitrary decisions. ${ }^{97}$ In this way, case law contributes to the development of predictable legal principles that regulate the conduct and activities of the people, organizations, and the State. The Practice Statement of the House of Lords, the predecessor of the UK Supreme Court, encapsulates all these benefits of judicial precedent in the English legal system. ${ }^{98}$

In Tañada v. Tuvera, ${ }^{99}$ the Supreme Court of the Philippines granted a writ of mandamus and "order[ed] respondents to publish in the Official Gazette all unpublished presidential issuances which are of general application, and unless so published, they shall have no binding force and effect." In addition to mandamus, FOIAs-also called Sunshine Laws in the United States - may be used to enforce one's right of public access to legal information. In Deaton v. Kidd, ${ }^{100}$ the Missouri Court of Appeals affirmed the judgment of the trial court that Ralph C. Kidd, the Director and Revisor of Statutes, purposefully violated Section 610.023 of

\footnotetext{
${ }^{97}$ See Gary Slapper \& David Kelly, The English Legal System: 2010-2011 134-39, 141-42 (11th ed. 2010) (Kindle edition).

${ }^{98}$ House of Lords Practice Statement [1966] 3 All ER 77.

99 Tañada, supra note 59.

${ }^{100}$ Deaton, 932 S.W.2d.
} 
the Missouri Sunshine Law by refusing to make available to Deaton a computerized copy of the Missouri Revised Statutes. The Court upheld the trial court's decision that the electronic product was public record and emphasized the primacy of legal information among all categories of public information. The trial court had ordered Kidd to make it available to Deaton for the cost of its duplication and to pay Deaton's litigation costs and fees. Before this action, it was made available to only private companies that entered into contracts with the Committee on Legislative Research to buy exclusive access.

The judicial recognition of every person's right of public access to legal information is not a recent development. It is also found in old cases on copyright in public or government-held information. Those cases are relevant because the absence of copyright in public documents is one of the indicators of the right of public access to them - the right to know of their existence, read and understand their contents, and reuse their texts freely. Wheaton $v$. Peters ${ }^{101}$ and Davidson $v$. Wheelock ${ }^{102}$ are examples of cases in which the courts have held that there could be no copyright in legal information resources because they are public information for the whole world and every person has the right to access them to know the law. Because there are still countries that have copyright in government works that include legal information, ${ }^{103}$ there is therefore the urgent need for a global prohibition of copyright in legal information, as I advocate in the next Part of this Article. ${ }^{104}$

Useful as it may seem, the enforcement of one's right of access to legal information under FOIAs is usually carried out on a piecemeal basis upon an individual's request, as I noted above. ${ }^{105}$ The type of enforcement that will have a strong effect on the overall public access to legal information must involve an order of a court to publish it in a permanent form for the benefit of the whole world, as is done, for example, on a website. Also, the discretionary nature of an order of mandamus makes it an inadequate mechanism for enforcement of one's right of public access to legal information. For example, in Victoria University of Wellington Students Association v. Shearer (Government Printer), ${ }^{106}$ although the New

\footnotetext{
${ }^{101}$ Wheaton v. Peters, 33 U.S. 591 (1834).

${ }^{102}$ Davidson v. Wheelock, 27 F. 61 (1886). See Ford, supra note 87, at 544-45.

${ }^{103}$ See, e.g., Copyright Act (1988) Cap. (C28), §4(1) (Nigeria) (“Copyright shall be conferred by this section on every work which is eligible for copyright and is made by or under the direction or control of the Government, a State authority or a prescribed International body.").

${ }^{104}$ See infra Section D.III.2.2 (stating that there should be no copyright in the texts of legal information and its official value-added features).

${ }^{105}$ See discussion supra Section C.I (discussing the existence of the right of public access to legal information under the general right of access to public or government-held information).

106 Victoria Univ. of Wellington Students Ass'n v. Shearer (Gov. Printer) [1973] 2 NZLR 21, 23 (SC), in David Harvey, Public Access to Legislative Information and Judicial Decisions in New Zealand: Progress and Process, 4 UTSLAWRW 105, 108 (2002).
} 
Zealand Supreme Court recognized the duty of the State to provide public access to legal information, it declined to grant an order of mandamus to compel the Government Printer to produce and supply copies of the Judicature Act 1908 that the plaintiff needed. The Court reasoned that mandamus could not lie against the Government Printer who was a servant of the Crown.

The existing isolated cases of judicial enforcement of the right of public access to legal information appear to prove one salient point: Members of the public are not sufficiently aware of the fact that they may be able to invoke provisions of FOIAs and the discretionary order of mandamus to compel their governments to grant them access, albeit limited access, to their legal information. But a definitive human right of public access to legal information would give the right the advantage of global awareness of its existence. That is part of the argument that I present in my proposal for the international human rights framework for the right of public access to legal information in Part $D$ below.

\section{A Proposal for the International Human Rights Framework for the Right of Public Access to Legal Information}

I examined the existence of the right of public access to legal information strictly as a legal right in the immediately preceding Part $\mathrm{C}$ above. In this Part, I review existing literature on the right of public access to legal information as a human right and examine why it should be formally recognized as a human right. I also discuss my proposal for its universal recognition as such, propose a UN Convention on the Right of Public Access to Legal Information, and outline the essential contents of the Convention.

\section{Existing Literature on the Right of Public Access to Legal Information as a Human Right}

Existing literature and some of the views on the right of public access to legal information as a human right are examined here to provide an important aspect of the background for the proposal discussed below.

\section{Previous Research and Views}

Jamar has been rightly referred to as "one of few scholars trying to construe a right of access." ${ }^{107}$ He deserves credit for being one of the pioneer contributors to this debate. Jamar suggested in his 2001 paper that the existence of the right of public access to legal information as a human right could be derived explicitly from the rights "to seek [and] receive information" in the Universal Declaration of Human Rights (UDHR), ICCPR, International Covenant on Economic, Social and Cultural Rights (ICESCR), regional treaties,

107 Laurens Mommers, Access to Law in Europe, in INNOVATING GoVERNMENT (Information Technology and Law Series 20) 383, 395 (S. van der Hof \& M. M. Groothuis eds., 2010). 
and national laws. He stated that "[t]he right of access to law is also implicit in other provisions of the International Covenant on Civil and Political Rights," such as the right "not to be subjected to arbitrary arrest and detention"; "[o]ther rights such as equality before tribunals"; the right to be protected against "arbitrary and unlawful interference with [one's] privacy, family, home or correspondence"; and the right to "nondiscrimination in employment, rights to unionize, [and] rights to social security." ${ }^{108}$

In my 2006 comparative study of public access to legislation in the United Kingdom and Nigeria, ${ }^{109}$ one of the statements in its conclusion was that, "[on] the global level, public access to legislation may be enhanced through the recognition and implementation of the right of access to legislation as a new human right." ${ }^{110}$ I had stated earlier in that study that public access to legislation qualified for recognition as a human right based on the "implications of lack of access to legislation highlighted above coupled with the philosophy underpinning the Montreal Declaration on Free Access to Law 2002."111

Mommers acknowledged Jamar's attempt to "construe a right of access". ${ }^{112}$ In his 2010 chapter contribution, Mommers discussed what he termed "several existing rights that might be supportive in construing a right of access to legal information, or even a right of accessibility of legal information." ${ }^{\prime 13}$ He examined the principle of legality, freedom of speech, right of access to justice, and transparency of government, which he referred to as "basic rights." He concluded that those basic rights provided a "careful 'yes'" answer to his research question: "Can a right of access to legal information be construed from the current legislative framework applicable to legal information?"114

In 2012, Danner, in his discussion primarily on open access to legal scholarship-that is, legal research publications that are not primary sources of law-attempted to use the free access to law principle as the possible means of making such publications accessible freely and openly. That quest led him to examine the Montreal Declaration on Free Access to Law and

\footnotetext{
108 See Steven D. Jamar, The Human Right of Access to Legal Information: Using Technology to Advance Transparency and the Rule of Law, 1 GLOBAL JURIST TOPICS No. 2 Art. 6 (Sept. 2001), http://ssrn.com/abstract=1148802 (emphasis added).

${ }^{109}$ See Mitee, supra note 15.

${ }^{110}$ See id. at 187 (emphasis added).

${ }^{111}$ See id. at $175-76$.

112 See Mommers, supra note 107, at 395.

${ }^{113}$ See id. at 392.

${ }^{114}$ See id. at 395.
} 
two other free-access international documents. ${ }^{115} \mathrm{He}$ identified the UDHR, ICESCR, and ICCPR as "the possible sources for a rights-based access argument," and stated that the three free-access international documents do not "argue for a right of open access to information ... [n]or do they discuss the [said] possible sources." ${ }^{116}$

Some scholars have simply declared or inferred in their publications that the right of public access to legal information is a human right. For example, Jones \& llako stated in their paper that discussed "US and Ugandan perspectives on legal information as a human right": "This paper is based on the proposition that access to information is a fundamental human right." ${ }^{117}$ They referred to, and appear to have adopted, the opinion of Danner mentioned above. Hellum \& Taj simply declared in their 2016 work: "Equal access to law and the right to legal information is a human right that, in principle, applies to all individuals regardless of time and place." ${ }^{\prime 18}$

\section{Gaps in the Existing Literature}

Only Mommers' work aimed specifically to discuss the right of public access to legal information as a human right. Although he did not directly use the term "human right" in his work, human rights are also referred to as "basic rights," which is the term he used. In addition, his reference to Jamar's work on the human right of access to legal information and his analysis based on human rights law, may be sufficient to conclude he was discussing the right of public access to legal information as a human right.

The discussions of Jamar, Mommers, and Danner do not contain arguments on why the right of public access to legal information should be recognized as a human right. They are confined to its derivative status from existing rights, which strengthen my contention in Section D.II.1 below, that its derivative existence makes the right illusory, ineffectual, and creates normative gaps. In fact, as quoted above, Mommers' conclusion contains a cautious acceptance that a right of access to legal information could be construed from the current legislative framework applicable to legal information. Danner only noted the possibility of its derivation from three international human rights instruments without discussing his

\footnotetext{
115 Richard A. Danner, Open Access to Legal Scholarship: Dropping the Barriers to Discourse and Dialogue, 7 JICLT, 65, 66-67 (2012). The other declarations are Budapest Open Access Initiative (Feb. 14, 2002), http://www.budapestopenaccessinitiative.org/read; Berlin Declaration on Open Access to Knowledge in the Sciences and Humanities (Oct. 22, 2003), https://openaccess.mpg.de/Berlin-Declaration.

${ }^{116}$ Danner, supra note 115, at 66 (emphasis added).

117 Yolanda Jones \& Caroline llako, Dynamic Law Libraries: Access, Development and Transformation in Africa and the United States, IFLA (June 16, 2015), http://library.ifla.org/1120/1/114-jones-en.pdf.

${ }^{118}$ Anne Hellum \& Farhat Taj, Taking What Law Where and To Whom? Legal Literacy as Transcultural 'Law-Making' in Oslo, in From Transnational Relations to Transnational LaWs: Northern European laws at the Crossroads (Anne Hellum, Shaheen Sardar Ali, \& Anne Griffiths eds. 2016).
} 
claim. Jamar appears to be more optimistic about the explicit derivative existence of the right. But the rights mentioned in his implicit derivation appear to be remote. None of them proposed the proper legal framework under which the right of public access to legal information could thrive as successfully as the established human rights, neither did they discuss its applicable principles or contents.

Both arguments of my previous study relate to the consequences of lack of access and the principle of free access that I discuss below in Section D.II.5 and Section D.II.7, respectively. The scope of that study was limited to legislation-one of the many categories of legal information listed in a footnote to my definition of the "right of public access to legal information" in Part C above. I now consider limiting human right protection to legislation to be a defect in that study. All categories of legal information are entitled to equal protection under one category of human rights, as I propose below. Second, the main focus of that study was a comparative evaluation of the state of public access to legislation in the United Kingdom and Nigeria. Therefore, the absence of a detailed discussion on public access to legislation as a human right may be understandable, like the discussions of Jamar and Danner.

The gaps in these existing discussions may explain why it is likely that there is no existing formal proposal for the universal recognition of the right of public access to legal information as a human right. Their different views reveal the fundamental problem with the feeble nature of the derivative existence of the right of public access to legal information as a human right. It appears that scholars have not realized the need for its formal universal recognition as a human right, based on convincing positive arguments. Yet, it is only such formal recognition that will make the right effectual and thereby contribute to free global public access to legal information.

This Article is my attempt to fill these gaps in the existing literature on the right of public access to legal information as a human right. It acknowledges and reinforces the existing arguments, and goes beyond them to make a positive case for the creation of the right of public access to legal information as a distinct human right based on eight reasons, as discussed in Section D.Il below.

II. Why the Right of Public Access to Legal Information Should be Recognized Universally as a Human Right

Here, I argue that the right of public access to legal information should be recognized formally as a human right for several reasons, ranging from its existing human right derivative status to the need to enjoy its numerous benefits, which are only achievable under an adequate global legal framework. 


\section{There are Normative Gaps Associated with Its Existing Derivative Status}

There is no international or regional human rights instrument that specifically created the right of public access to legal information as a human right. ${ }^{119}$ Nevertheless, it is not just a legal right, which I have established that it is, in Part $\mathrm{C}$ above; it is also a human right with a derivative status. That means it acquires its status from a parent human right, which is the right to freedom of expression and the press. ${ }^{120}$ Although the UDHR may not have the force of a binding treaty, ${ }^{121}$ its Article 19 is the global source of the human right of freedom of expression and the press. It has been replicated as an enforceable human right in the ICCPR, ${ }^{122}$ regional human rights instruments, ${ }^{123}$ and national constitutions. ${ }^{124}$

The first part of Article 19(2) of the ICCPR-a binding instrument that was adopted nearly twenty years after the UDHR-states: "Everyone shall have the right to freedom of expression; this right shall include freedom to seek, receive and impart information and ideas of all kinds, regardless of frontiers, either orally, in writing or in print, in the form of art, or through any other media of his choice." Its equivalent provisions in other human rights instruments ${ }^{125}$ and national constitutions ${ }^{126}$ have several variations.

It is significant that some courts have interpreted the traditional right to receive information as the right of access to public information. For example, the Inter-American Court of Human

\footnotetext{
${ }^{119}$ See Jamar, supra note 108.

${ }^{120}$ For opinions relating to how it may be derived or construed as a human right, see id. See also Mommers, supra note 107 , at 392-97.

${ }^{121}$ Some scholars hold the opinion that the UDHR is binding as customary international law. See generally Hurst Hannum, The Status of the Universal Declaration of Human Rights in National and International Law, 25 GA. J. INT'L \& COMP. L. 287 (1995); Jochen von Bernstorff, The Changing Fortunes of the Universal Declaration of Human Rights: Genesis and Symbolic Dimensions of the Turn to Rights in International Law, 19 EJIL 903 (2008); What is the Universal Declaration of Human Rights?, AUSTL. HUM. RTS. СOMM'N, https://www.humanrights.gov.au/publications/whatuniversal-declaration-human-rights (last visited July 6, 2017).

122 International Covenant on Civil and Political Rights, art. 19, para. 2, Dec. 16, 1966, 999 U.N.T.S. 171.

${ }^{123}$ See, e.g., European Convention on Human Rights art. 10, Nov. 4, 1950, 213 U.N.T.S. 221; African Charter on Human and Peoples' Rights, art. 9; League of Arab States, Arab Charter on Human Rights, art. 32., May 22, 2004, reprinted in INTERNATIONAL HUMAN RIGHTS REPORTS 893 (2005) [hereinafter Arab Charter]. The Arab Charter expressly provides for the right of access to public information, in addition to freedom of opinion and expression.

124 See, e.g., Bundesverfassung [BV] [CONStITUtION] Apr. 18, 1999, SR 101, art. 16 (Switz.); Constitution of Malta (1964), art. 41; CONSTITUTION OF NIGERIA (1999), § 39.

125 See, e.g., Organization of American States, American Convention on Human Rights, art. 13(1), 22 Nov. 1969, O.A.S.T.S. No. 36, 1144 U.N.T.S. 123 [hereinafter ACHR].

${ }^{126}$ See, e.g., CONSTITUTION OF NIGERIA (1999), § 39(1).
} 
Rights ruled in Claude-Reyes v. Chile ${ }^{127}$ that Article 13 of the American Convention on Human Rights guarantees the right of access of every person to government-held information and the duty of the government to provide the required access. Although the European Court of Human Rights has over the years been reluctant to give it the same outright recognition under Article 10 of the European Convention on Human Rights, it did so implicitly in Matky v. Czech Republic. ${ }^{128}$

The 2009 Report of the Special Rapporteur for Freedom of Expression of the Inter-American Commission on Human Rights contains elaborate principles of the right of access to public information as "a specific manifestation of the freedom of expression." ${ }^{129}$ More recently, the 2013 Report of the UN Special Rapporteur on the Promotion and Protection of the Right to Freedom of Opinion and Expression described it as "one of the central components of the right to freedom of opinion and expression." ${ }^{130}$ From the foregoing analysis, it is clear that because the right to freedom of expression is a human right that encompasses access to public information, and because legal information is a major component of public information, ${ }^{131}$ the right of public access to legal information is therefore also a human right.

Its derivative status as a human right is associated with normative gaps in the existing human rights instruments relating to it. For example, it is not identified or defined specifically as a human right and there is no detail on any of its various aspects. Its existence may therefore be susceptible to controversy. Because "[h]uman rights are intended to formally define the thresholds that identify situations in which human dignity is threatened or violated," 132 its derivative status is a defect in its existence as a human right. The solution to this defect is its formal universal recognition under a distinct international instrument. The instrument will contain express provisions on all aspects of the right and thereby eliminate the adventure to conjecture its existence or strain it from existing isolated human rights instruments. ${ }^{133}$ In

\footnotetext{
127 Claude-Reyes v. Chile, Merits, Reparations, and Costs, Judgment, Inter-Am. Ct. H.R. (ser. C) No. 151 (Sept. 19, 2006).

128 Matky v. Czech Republic, App. No. 19101/03 Eur. Ct. H.R. 1205 (July 10, 2006).

129 Org. of Am. States, Report of the Special Rapporteur for freedom of Expression 1 (2009), http://www.oas.org/dil/access_to_information_IACHR_guidelines.pdf.

${ }^{130}$ Frank La Rue (Special Rapporteur on the Promotion and Protection of the Right to Freedom of Opinion and Expression), Rep. of the Special Rapporteur on the Promotion and Protection of the Right to Freedom of Opinion and Expression, U.N. Doc. A/68/362, at 3 (Sept. 4, 2013).

${ }^{131}$ Deaton, 932 S.W.2d.

132 HelpAge International, International Human Rights Law and Older People: Gaps, Fragments and Loopholes, UN DEP'T OF ECON. AND SOC. AFFAIRS (2012), http://social.un.org/ageing-workinggroup/documents/GapsinprotectionofolderpeoplesrightsAugust2012.pdf.

${ }^{133}$ See, e.g., Jamar, supra note 108.
} 
that way, it will remove the possibility of any judicial indifference to its outright recognition, such as the attitude of the European Court of Human Rights to Article 10 of the European Convention on Human Rights. ${ }^{134}$

It is noteworthy that Article 14 of the UN Declaration on Human Rights Defenders persuades governments to undertake "[t]he publication and widespread availability of national laws and regulations and of applicable basic international human rights instruments." Unfortunately, this Declaration, which has the most relevant general provisions on public access to legal information, is not a binding instrument in international human rights law, similar to other Declarations. ${ }^{135}$ Its implementation is therefore discretionary.

\section{To Provide the Human Rights Framework for its Promotion, Protection, and Actualization}

To remedy the defect in its existing derivative status discussed above, the right of public access to legal information should be formally recognized as a human right in a Convention. Such formal recognition-whose importance is revealed by the United Nations' quoted statement in Section D.II.4 below - will provide the global legal framework necessary for its promotion, protection, and actualization. The Office of the UN High Commissioner for Human Rights (OHCHR) defines human rights as the "universal legal guarantees protecting individuals and groups against actions and omissions that interfere with fundamental freedoms, entitlements and human dignity." ${ }^{136}$ Governments are the principal duty bearers that have human rights obligations to do, and to refrain from doing, certain things that affect the lives of people as human beings. ${ }^{137}$ The international human rights framework is the global legal mechanism for promoting, protecting, and realizing the inalienable rights of people, irrespective of their race, culture, religion, gender, station in life, and other differences. I will examine here how this applies to global access to legal information.

First, human rights are international norms and values aimed at achieving justice necessary for the holistic wellbeing of human beings. I agree with Douglas-Scott's claim that "human rights remain a powerful symbolic and actual force for justice and a better focus for its achievement." ${ }^{\prime 138}$ As the author rightly argues, the concept of justice is so value-laden and

\footnotetext{
${ }^{134}$ See Matky case, supra note 128 and the accompanying text.

135 See Glossary of Terms Relating to Treaty Actions, UN TREATY COLLeCtion, https://treaties.un.org/Pages/Overview.aspx?path=overview/glossary/page1_en.xml (last visited July 6, 2017).

${ }^{136}$ Office of the UN High Comm'r for H.R., Frequently Asked Questions on a Human Rights-Based Approach to Development Cooperation 1 (2006), http://www.ohchr.org/Documents/Publications/FAQen.pdf.

${ }^{137} / d$.

${ }^{138}$ Sionaidh Douglas-Scott, Human Rights as a Basis for Justice in the European Union 11-13 (WZB Discussion Paper No. SP IV 2015-804, 2015), https://www.econstor.eu/dspace/bitstream/10419/121482/1/838036562.pdf. The quote is from the abstract to the article.
} 
contested that it is easier to understand justice from the perspective of what is considered injustice. ${ }^{139}$ The international human rights framework is the most potent global weapon against the various manifestations of injustice. That is the basis for the specific Conventions on critical aspects of injustice. For instance, the unjust deprivations suffered by persons with disabilities worldwide led to the adoption of the UN Convention on the Rights of Persons with Disabilities (CRPD). ${ }^{140}$ The injustice associated with liability under inaccessible lawsincluding how it is analogous to the injustice from liability under both retroactive and nonexistent legislation-is discussed below. ${ }^{141}$ It is therefore necessary to provide a universal remedy for this dimension of injustice through the international human rights framework for public access to legal information.

Second, the international human rights framework sets the minimum global standards that impose binding obligations, under which the duty bearers are accountable. ${ }^{142}$ On the justification for the CRPD, the United Nations explains that "[a] universal, legally binding standard is needed to ensure that the rights of persons with disabilities are guaranteed everywhere." ${ }^{143}$ Elevating the right of public access to legal information to the status of a human right will therefore provide the universal standards to which the duty bearers must conform. The obligations of the duty bearers are expected to help them to review their laws, programs, policies, and practices to make sure that they conform to these standards, which is the practice in democratic countries like Australia. ${ }^{144}$ It will particularly help countries with virtually no legal framework and policies on public access to legal information-such as Nigeria - to adopt such frameworks and policies. ${ }^{145}$ The result promises to be a significant improvement in global access to legal information that is now indispensable due to technology-driven globalization that generates borderless interactions in virtually every area of life and is producing an ever-shrinking global space. ${ }^{146}$

\footnotetext{
${ }^{139} / d$.

${ }^{140}$ The preamble to the CRPD mentions these deprivations and the need to remedy the injustice.

${ }^{141}$ See discussion infra Section D.II.5 (discussing the remedy for the injustice from the ignorantia juris doctrine).

142 Office of the UN High Comm'r for H.R., Who will be Accountable? Human Rights and the Post-2015 Development Agenda 10 (2013), http://www.ohchr.org/Documents/Publications/WhoWillBeAccountable.pdf.

143 United Nations, Frequently Asked Questions regarding the Convention on the Rights of Persons With Disabilities, http://www.un.org/esa/socdev/enable/convinfofaq.htm\#qa (last visited July 6, 2017).
}

144 Attorney-General's Dep't, Australia's human Rights Framework 9 (Apr. 2010), https://www.ag.gov.au/Consultations/Documents/Publicsubmissionsonthedraftbaselinestudy/AustraliasHumanRi ghtsFramework.pdf.

${ }^{145}$ See supra notes 21-22 and accompanying text (discussing poor public access to legal information in Nigeria).

${ }^{146}$ See Claire M. Germain, Worldwide Access to Foreign Law: International \& National Developments Toward Digital Authentication 1-2 (University of Florida Levin College of Law Working Papers No. 1, 2012), http://scholarship.law.ufl.edu/cgi/viewcontent.cgi?article=1000\&context=working. 
By setting the minimum global standards for which the duty bearers are accountable, the human rights approach has become a universally acceptable means of making governments and non-State actors liable for violations of the inalienable rights of people worldwide. It does this through enforceable sanctions. ${ }^{147}$ Article 41 of the UN Charter provides the general framework for the UN sanctions regime under international law. The Security Council determines the appropriate sanctions in any particular situation, which may include interruption of economic and communication relations and severance of diplomatic relations. Sanctions for the violation of human rights can have serious reputational, economic, and diplomatic consequences. For instance, Nigeria was suspended from the Commonwealth two days after the Nigerian military government executed Ken Saro-Wiwa and other environmental rights activists in 1995 in circumstances that amounted to gross human rights violations. ${ }^{148}$ It is true that many dictatorial regimes defy sanctions imposed as punishment for human rights abuses and thereby render such coercion ineffectual or even counterproductive. ${ }^{149}$ But that is part of the general problem of enforcement of compliance with international law. Punitive sanctions may still serve as deterrents to responsible governments and organizations that value their reputation and endeavor to uphold the rule of law and the other tenets of democracy.

Third, the human rights framework is the most powerful tool that civil society uses to put pressure on governments, individuals, and organizations to do the right thing. One of the reasons for the existing poor state of public access to legal information ${ }^{150}$ may be the ineffectual involvement of civil society on a global scale in the campaign. For instance, FALM has since its inception concentrated their efforts on the provision of alternative sources of legal information by third parties to the detriment of putting pressure on governments to do so as a public duty to the people. In accordance with the prevailing practice, once there is an international human rights framework for promoting, protecting, and actualizing the right of public access to legal information, civil society organizations will enter the arena to campaign for and monitor global compliance with the universal standards. This comports with the argument by Ashcroft that the human rights framework provides "long-established common language, rhetoric and institutional practice" as a platform for civil society, intergovernmental and international bodies to engage in "identifying and protecting the

\footnotetext{
147 See UN Sanctions: What They Are, How They Work, and Who Uses Them, UN NeWS CENTRE (MAY 4, 2016), www.un.org/apps/news/story.asp?NewsID=53850\#.V13VY1QrLIV.

148 See Nigeria Suspended from the Commonwealth, THE COMMONWEALTH

(1995), http://thecommonwealth.org/history-of-the-commonwealth/nigeria-suspended-commonwealth.

149 See generally Dursun Peksen, Better or Worse? The Effect of Economic Sanctions on Human Rights, 46 JPR 59 (2009). North Korea, Iran, Cuba, and Zimbabwe are examples of dictatorial regimes that have refused to bow to the pressure from sanctions.

150 See, e.g., sources cited supra notes 21-23 and accompanying text (discussing poor public access to legal information in Nigeria and Mali).
} 
interests of individuals and groups worldwide." ${ }^{151}$ The advocacy by civil society complements the international mechanisms of the United Nations for implementing and monitoring compliance with international human rights obligations of governments and non-State actors. $^{152}$

\section{It Should be Recognized as a Human Right Based on the Precedent of the Aarhus Convention}

The Aarhus Convention ${ }^{153}$ contains the right of public access to legal information relating to the environment. It defines "environmental information" in Article 2, paragraph 3(b) to include information on public agreements, policies, and legislation related to the environment. Consequently, the Convention is a formal recognition of the right of public access to a limited range of legal information specifically on environmental matters.

The Convention enhances environmental human rights ${ }^{154}$ and therefore it is a precedent that it is possible, and even desirable, to have Conventions on crucial aspects of public information that are not adequately protected under the existing human rights regime. As there is hardly any aspect of public information that is more crucial than legal information that regulates the conduct and activities of every person and the State, ${ }^{155}$ which every person has a duty to know and is presumed ${ }^{156}$ to know, the Aarhus Convention therefore reinforces my argument for an international human rights framework for the right of public access to legal information.

\footnotetext{
${ }^{151}$ Richard E. Ashcroft, Could Human Rights Supersede Bioethics? 10 H.R.L. REv. 639, 643-44 (2010).

152 See OfFice of the UN High Comm'R for H.R., The United Nations Human Rights Treaty SYStem 19-39 (2012), http://www.ohchr.org/Documents/Publications/FactSheet30Rev1.pdf (mechanisms for implementation of human rights standards).

${ }^{153}$ Aarhus Convention, supra note 70.

${ }^{154}$ See generally Alan Boyle, Human Rights and the Environment: Where Next?, 23 EJIL 613-42 (2012); UN Econ. Comm'n for Europe (UNECE) Aarhus Convention Secretariat, The Role of the Aarhus Convention in Promoting Good Governance Human Rights (Sept. 2012), http://www.ohchr.org/Documents/Issues/Development/GoodGovernance/Corruption/ECONOMIC_COMMISSION _FOR_EUROPE.pdf; UNECE, What People are Saying about the Aarhus Convention, http://www.unece.org/fileadmin/DAM/env/pp/documents/statements.pdf (last visited July 6, 2017).

${ }^{155}$ Deaton, 932 S.W.2d.

${ }^{156}$ See INGRAM, supra note 62.
} 


\section{The Right of Public Access to Legal Information has the Basic Characteristics of Human Rights}

The right of public access to legal information should be recognized universally as a human right because it possesses the basic characteristics of human rights. First, human rights are inalienable. It is significant that the very first paragraph of the preamble to the UDHR declares the inalienability of human rights. Inalienability of human rights means they are inherent in human beings and intertwined with their existence. The United Nations aptly states it thus:

Human rights law places an obligation on States to act in a particular way and prohibits States from engaging in specified activities. However, the law does not establish human rights. Human rights are inherent entitlements which come to every person as a consequence of being human. Treaties and other sources of law generally serve to protect formally the rights of individuals and groups against actions or abandonment of actions by Governments which interfere with the enjoyment of their human rights. ${ }^{157}$

Inalienability of the right of public access to legal information is based on the general legal principle of justice that is the foundation of legal rules and regulations, humane and civilized policies, judicial decisions, and human rights. The application of the principle that every person has a duty to know, and is therefore presumed to know, the law can only be justified where the law exists in a state that everybody can access and know its full contents. ${ }^{158}$ That is the only way to avoid the manifest injustice in punishing people for violating any law whose texts are unknowable, which Jeremy Bentham described as tyrannical. ${ }^{159}$

The right of public access to legal information is an inalienable right because every person lives in a society that is governed by law that they are bound to know, where ignorance of the law is no excuse. Nobody can avoid its direct application because nobody is exempt from obeying the law; everybody is subject to liability for contravening it. Additionally, it is an inalienable right because it borders on an aspect of personal freedom that is inherent in human existence. Knowledge of the legal principles that regulate one's conduct and activities provides the freedom needed to make personal choices. These choices include the

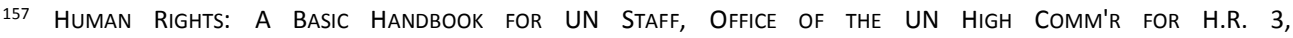
http://www.ohchr.org/Documents/Publications/HRhandbooken.pdf (last visited July 9, 2017) (emphasis added).

${ }^{158}$ See supra Section D.II.5 (discussing the remedy for the injustice from the ignorantia juris doctrine).

${ }^{159}$ BENTHAM \& BOWRING, supra note 5. 
exercise of one's legal rights and avoidance of liability by complying with the law. A society in which people are forced to comply with inaccessible laws lacks this basic freedom.

Second, human rights are universal in terms of their application to the entire human race, without any kind of distinction. ${ }^{160}$ According to the United Nations, "[t]he principle of universality of human rights is the cornerstone of international human rights law."161 Although the debate on the correctness of the principle of universality of human rights goes on, ${ }^{162}$ there are human rights that are clearly universal, and the right of public access to legal information is one of them. It is universal because it applies to every human being who has attained the age of legal responsibility. Every person has a legal obligation to know the law and pays the price, sometimes a very high price that could even be a death sentence, for its contravention.

Third, human rights are interdependent and interrelated. This means they are connected to each other, intertwined, and together make a complete whole. The right of public access to legal information is interwoven with other human rights ${ }^{163}$ and it is an empowerment right that is essential for the enjoyment of other distinct human rights, such as the right to a fair trial. The purpose of the fair trial of any person by any court or tribunal-guaranteed under Article 14 of the ICCPR and other human rights instruments-is to achieve justice in the determination of their rights and obligations and of any criminal charge against them. It includes the requirement for adequate time and facilities for the preparation of one's defense, and the right to defend oneself by self-representation or through legal assistance of one's own choosing. All these fair trial safeguards depend on free and adequate public access to legal information.

Regina v. Chambers ${ }^{164}$ illustrates the importance of access to comprehensive and up-to-date legal information to a fair trial. It was in that case that the England and Wales Court of Appeal discovered that ignorance of the current position of the law on the part of the judiciary and lawyers-due to inadequate access to legislation-had led to the delivery of wrong

\footnotetext{
${ }^{160}$ G.A. Res. 217 (III) A, Universal Declaration of Human Rights, art. 2 (Dec. 10, 1948) [hereinafter UDHR].

161 What are Human Rights?, OFFICE OF THE UN HIGH COMM'R FOR H.R., http://www.ohchr.org/EN/Issues/Pages/WhatareHumanRights.aspx (last visited July 6, 2017).

162 For discussions on the universality of human rights, see generally Robert Spano, Universality or Diversity of Human Rights? 14 H.R.L. ReV. 487 (2014); Friedrich Wilhelm Graf, The Controversial Universality of Individual Human Rights, 26 VERBUM ET ECCLESIA 700 (2005); Louis Henkin, The Universality of the Concept of Human Rights, Annals of the American Academy of Political and Social Science, 506 HUMAN RIGHTS AROUND THE WORLD 10 (Nov., 1989); John O'Manique, Universal and Inalienable Rights: A Search for Foundations Source, 12 H.R.Q. 465 (Nov. 1990).

${ }^{163}$ See Mitee, supra note 15, at 76-92 (discussing the right of access to public information, right to education, right to indigenous languages, disability rights, and the right of access to public service and participation in public affairs as human rights inherent in the right of access to legislation).

${ }^{164}$ Regina v. Chambers [2008] EWCA (Crim) 2467 (Eng.).
} 
judgments from 2001 to 2008. The magnitude of the error led the Crown Prosecution Service to review the cases of more than 2,615 defendants. Some of the defendants successfully appealed their confiscation orders that were made in ignorance of the repealed legislation. ${ }^{165}$

\section{To Remedy the Injustice from the Application of the Ignorantia Juris Doctrine Where the Law Is Inaccessible}

The ignorantia juris doctrine has an ancient origin. Although the exact date of its first use in common law may be unknown, one of the references to it dates back to 1530 when the Dialogue II was published. ${ }^{166}$ This legal doctrine has survived several centuries of hostility and it continues to enjoy statutory sanctuary as the foundation of the criminal justice system. ${ }^{167}$ It is a universal doctrine that transcends national barriers.$^{168}$ Therefore, any hardship or injustice associated with its application has global consequences.

John Selden stated this doctrine, more than 300 years ago, in his famous quote: "Ignorance of the Law excuses no man; not that all Men know the Law, but because 'tis an excuse every man will plead, and no Man can tell how to confute him." ${ }^{169}$ Its application in criminal law usually depends on the distinction between ignorance, or mistake, of law and of fact. ${ }^{170}$ The scope of this Article is confined to the general application of the doctrine in relation to the knowledge of the authentic and official texts ${ }^{171}$ of legal information that contain the legal principles that regulate the conduct and activities of people, organizations, and the State.

\footnotetext{
${ }^{165}$ Chambers Review, supra note 7. See also Mitee, supra note 15, at 167-68 (stating the possibility of per incuriam decisions due to lack of access to legislation).

${ }^{166}$ See Paul Matthews, Ignorance of the Law is No Excuse? 3 LEGAL STUD. 174 (1983) (listing ancient statements and references on the maxim of "ignorance of the law is no excuse").

167 See Mitee, supra note 15, at 37. See, e.g., Model PenAl Code § 2.02(9) (U.S.); Criminal Code Act 1995 (Cth) s 9.3(1) (Austl.); Criminal Code Act (1916) Cap. (C38), § 22 (Nigeria); Crimes Act 1961, s 25 (N.Z.); Criminal Code, R.S.C. 1985, c. C-46 s. 19 (Can.).

168 Julia P. Sams, The Availability of the "Cultural Defense" as an Excuse for Criminal Behavior, 16 GA. J. INT'L \& COMP. L. 335 (1986).

169 John Selden, The TABle-Talk of John Selden 82 (London, John Russell Smith, 2nd ed. 1856), https://archive.org/details/tabletalkofjohns00seldiala.

170 For discussions on mistake of law and mistake of fact in criminal law, see generally Mohamed Elewa Badar, Mens Rea-Mistake of Law \& Mistake of Fact in German Criminal Law: A Survey for International Criminal Tribunals, 5 INT'L CRIM. L. REV. 203 (2005); Re'em Segev, Moral Rightness and the Significance of Law: Why, How, and When Mistake of Law Matters, 64 U.T.L.J. 36 (2014).

171 See supra note 13 (providing a definition of authentic texts of legal information). See also supra note 14 (providing a definition of official texts of legal information).
} 
From Selden's statement above, it appears that the doctrine was devised as a dual weapon of convenience as well as necessity against even a genuine plea of a person's inability to know the law. Such genuine ignorance of the law may arise in two different situations. First, the volume of legal information is so large ${ }^{172}$ and the number of statutory crimes so many ${ }^{173}$ that even lawyers and judges cannot know every law. ${ }^{174}$ That means members of the public are in a much worse situation. Yet, allowing the defense of ignorance of the law on the ground of impossibility of knowing every law due to the enormous volume of legal information will enthrone a dangerous system of impunity, as it will be virtually impossible to secure any successful prosecution, especially for mala prohibita offenses. ${ }^{175}$ This stark reality has therefore made the doctrine a necessary evil. The court stated it in $R$. v. Campbell thus: "The principle that ignorance of the law should not be a defense in criminal matters is not justified because it is fair, it is justified because it is necessary, even though it will, sometimes produce an anomalous result." ${ }^{\prime 176}$

Second, ignorance of the law arises due to its inaccessibility, which is in turn due to inadequate publication. The doctrine is merely used here as a weapon of convenience. This Article focuses on two aspects of this second category-discussed below-and the solutions to them, and considers the massive volume of legal information as a factor that contributes to the problem of inaccessibility.

The first aspect is where the law has not been adequately published and is therefore inaccessible to the people affected by it. In United States v. Casson, ${ }^{177}$ Casson was convicted of crimes he committed about six hours after President Lyndon B. Johnson had signed the amending statute in question into law on December 27, 1967. The Court of Appeals held

\footnotetext{
172 See, e.g., Richard CRAcknell \& Rob Clements, Acts AND InStruments: The Volume OF UK LEGISLATION 1950 to 20147 (2014), http://researchbriefings.files.parliament.uk/documents/SN02911/SN02911.pdf.

${ }^{173}$ See, e.g., Michael Anthony Cottone, Rethinking Presumed Knowledge of the Law in the Regulatory Age, 82 TENN. L. REV. 137, 142-44 (2015); John S. Baker, Revisiting the Explosive Growth of Federal Crimes, THE HERITAGE FOUNDATION (June 16, 2008), http://www.heritage.org/research/reports/2008/06/revisiting-the-explosive-growth-of-federalcrimes; Gary Fields \& John R. Emshwiller, Many Failed Efforts to Count Nation's Federal Criminal Laws, THE WALL $\begin{array}{llll}\text { StREET JOURNAL (July 23, 2011), } & \end{array}$ http://www.wsj.com/articles/SB10001424052702304319804576389601079728920.

${ }^{174}$ See Montriou v. Jefferys (1825) 2 Car. \& P. 113, in 12 REPORTS OF CASES ARgUED AND DETERMINED IN THE ENGLISH CouRTS of COMMON LAW 50, 52 (Thomas Sergeant \& John C. Lowber eds. 1839); Fields \& Emshwiller, supra note 173 (quoting Ronald Gainer's statement that "[y]ou will have died and resurrected three times," and still be laboring to count the exact number of the U.S. federal crimes).

${ }^{175}$ See infra note 297 and accompanying text (mala prohibita offenses).

${ }^{176}$ R. v. Campbell [1972] 2 All E.R. 353 (Eng.), in CASES ANd Materials on Criminal LAW ANd Procedure 522 (Martin L. Friedland ed., 5th ed. 1978) (emphasis added); STUART, supra note 63, at para. 32 (CanLII) (discussing the justification of the doctrine of ignorance of the law is no excuse).

177 United States v. Casson, 434 F.2d 415 (D.C. Cir. 1970).
} 
that he was properly convicted under the statute because on the day he committed the offenses, there was no express constitutional or statutory requirement of publication of legislation before they became effective. In addition, the Court held that the widespread publication of the bill, its extensive public hearings, the report of the debates on it, and news media publicity of its provisions constituted sufficient notice to members of the public, including Casson. It is not difficult to see the Court's error in Casson because the publicity of a bill in the legislative process does not amount to publication of the eventual legislation after assent. The legal framework for publication of U.S. legislation was clearly defective and it was unjust to expect every person in a populous country like the United States to know the full texts of a law within six hours of its enactment, especially because public access to information in 1967-when the law in question was made-was not as efficient as it is today.

The second aspect is where, even if the law were adequately published, the peculiar circumstances of a particular person affected by it would make it inaccessible to that person. In Rex v. Bailey, ${ }^{178}$ the Government of England had enacted legislation that criminalized a conduct that previously was not a criminal offense. Although the court found that it was impossible for the accused person-Richard Bailey, the captain of a vessel-to know of the new law because he was at sea when the statute was enacted and he was still there when he committed the prohibited act, it rejected his defense of ignorance of the new legislation and found him guilty. Cognizant of the untold injustice in its judgment, the court noted that the accused person was guilty of committing an offense whose existence was beyond his ability to know, but recommended a pardon as the appropriate remedy after his conviction. ${ }^{179}$ That was one instance of slavish adherence to the ignorantia juris doctrine, irrespective of the magnitude of the injustice it caused.

Any conviction in circumstances similar to those in Bailey and Casson violates the victim's human right against liability under ex post facto legislation. ${ }^{180}$ Brudner rightly stated the similarity between liability under a retroactive law and an unpublished law thus: "Liability under a retroactive law violates [the same] principles [as] liability under a regulation that was signed into law before the defendant's breach but not published so that dutiful care could discover it." ${ }^{181}$ He concluded correctly that "an absolute duty to know the law (where

\footnotetext{
${ }^{178}$ Rex v. Bailey (1800) 168 Eng. Rep. 651 (Eng.).

179 Id. at 653; see also Matthews, supra note 166, at 179-85 (discussing some of the cases on the application of the doctrine of ignorance of the law is no excuse).

${ }^{180}$ See, e.g., International Covenant on Civil and Political Rights art. 15, Dec. 16, 1966, 999 U.N.T.S 171 [hereinafter ICCPR].

181 See Alan Brudner, Punishment and Freedom: A liberal Theory of Penal Justice 186-87 (2009) (discussing the similarity between liability under retroactive and unpublished law).
} 
the law is not knowable to reason) is a duty to know it even if it is impossible to know, such as when it does not yet exist."182

In both Bailey and Casson, each accused person who could not have known of the existence of the new law and its contents, was in the same position as if he was convicted under an adversely retrospective legislation. To the extent that the accused person had no means of knowing about the legislation and its provisions, the scenario was similar to a situation where the law never existed. I had, in a previous study before Brudner, stated that any law whose existence is unknown because it is impossible to know-due to a complete or partial lack of access-is analogous to nonexistent law, and both types of law cause similar grave injustice. ${ }^{183}$ Every person has the right to know the law that they have the duty to obey.

The gravity of the injustice from liability under ex post facto legislation led to the creation of the human right against it, and this right is enshrined in human rights instruments. ${ }^{184}$ Because the magnitude of the injustice under both ex post facto and inaccessible laws is similar, they should also have a similar effect in terms of liability. Therefore, there should be no liability for contravention of the provision of any law that was inaccessible to the extent that the person affected could not have known of its existence and exact contents at the time of the conduct in question. The application of this principle should have led the court in the Bailey case to declare the accused person not guilty. Unfortunately, the court in that case upheld the ignorantia juris doctrine and recommended pardon as a remedy for the obvious injustice its judgment caused the accused person. The best way to remedy such injustice on a global scale is to promote, protect, and actualize this right against liability under inaccessible law as a component of the human right of public access to legal information that I advocate in this Article. ${ }^{185}$

\section{To Realize the Numerous Benefits Derivable from Adequate Public Access to Legal Information}

Recognition of the right of public access to legal information as a human right will significantly improve global access to legal information with its attendant numerous benefits. First, adequate public access to legal information enhances sustainable development. Out of the numerous definitions of "sustainable development", the one in the World Commission on Environment and Development Report (1987) has now been generally accepted. The Report refers to sustainable development as "[d]evelopment that meets the needs of the present without compromising the ability of future generations to meet their

\footnotetext{
182 Id.

${ }^{183}$ See Mitee, supra note 15, at 165-67.

${ }^{184}$ See supra text accompanying note 180 (discussing the right against ex post facto laws).

${ }^{185}$ See infra Section D.III.2.15 (discussing the proposal that there should be no liability under any inaccessible law).
} 
own needs." ${ }^{186}$ Adequate public access to legal information facilitates sustainable development by contributing to the awareness of social, economic, and development policies and regulations; promotion of trade and foreign investment; ${ }^{187}$ transparency; $^{188}$ and protection of the rights of minorities, migrants, etc. ${ }^{189}$

Second, it facilitates effective law reform. Law reform commissions have become indispensable in every democratic government that upholds the principles of justice and the rule of law. Their primary duties include identifying the existing laws in a jurisdiction or legal system that require amendment to make them relevant to the current circumstances of the society, repealing obsolete laws, and making recommendations for enactment of necessary new laws. Obviously, successful law reform programs require adequate access to all the existing laws in the jurisdiction in question.

Third, adequate public access to legal information enables effective legal research for various purposes. For example, it promotes justice by helping the judiciary to avoid decisions in ignorance of the current position of the law. The courts should not rely solely on the position of the law in the arguments of lawyers who appear before them; they have a duty to verify the authenticity of those arguments from their own independent research. In Regina v. Chambers, ${ }^{190}$ neither the England and Wales Court of Appeal, the prosecution, nor the defense lawyer knew that a subsidiary legislation upon which the case was based had been repealed about seven years earlier. A lawyer at the Revenue and Customs Prosecutions Office who was working on an application in another case discovered the fact of the repeal and quickly alerted the prosecution because she was fortuitously aware of the draft of the judgment that was scheduled for the next day. The prosecution then disclosed it to the Court, based on which the Court allowed the appeal and quashed the confiscation order. Knowledge of the repeal led to the review of the previous cases of more than 2,615 defendants based on the mass error. ${ }^{191}$ Lord Justice Toulson blamed the error on

\footnotetext{
${ }^{186}$ World Comm'n on Env't and Dev., Rep. of the World Comm'n on Env't and Dev.: Our Common Future (1987) adopted by G.A. Res. A/RES/42/187 (Dec. 11, 1987), http://www.un-documents.net/our-common-future.pdf. The Commission is also known as the Brundtland Commission.

187 See Jamar, supra note 108 ("Businesses seeking to invest overseas would be better able to make investment decisions based in part on the content of the law more easily.").

188 See id. ("A foundational principle of the rule of law is governmental transparency, i.e., governments operating not secretly, but openly. One aspect of this transparency is ready access to the law.").

189 See UN Public Admin. Network, Providing Access to Legal Information to Accelerate Sustainable Development, http://workspace.unpan.org/sites/Internet/Documents/UNPAN94768.pdf (last visited July 6, 2017).

190 Regina v. Chambers [2008] EWCA (Crim) 2467.

${ }^{191}$ Chambers Review, supra note 7.
} 
inaccessible legislation. ${ }^{192}$ Adequate public access to legal information also improves justice by enhancing knowledge of the law by law enforcement agencies at all levels.

It guides the legislature in the performance of their law-making function that requires reliable legal research. The reason is that every legislature is expected to be aware of all the existing laws in force in the jurisdiction. Legal practitioners depend on adequate public access to legal information for the performance of their professional duties: To provide reliable legal opinions to their establishments and clients, and to present valid legal arguments in the court based on the current principles of law contained in up-to-date sources. As stated above, the lawyers' ignorance of a repealed subsidiary legislation in the Chambers case was blamed on inaccessible legislation.

Further, it is indispensable to global legal scholarship. ${ }^{193}$ Academics, students, authors, and others interested in knowing the current position of the law on any subject cannot do without adequate access to authentic legal information. Only comprehensive, up-to-date, and free official online legal information databases of the various jurisdictions can meet the need for reliable national and transnational legal research in today's technology-driven world. ${ }^{194}$ For example, a Canadian human rights intern with Avocats sans frontières Canada, who was frustrated with the unavailability of Malian legal information online, said:

For a Canadian law student, the idea of not being able to access legal information online is unthinkable. But when I look for information about Malian law, it can be difficult-often impossible-to find even basic legal texts. Even when information is available online, it's often out of date or incomplete. ${ }^{195}$

Additionally, it is necessary for effective legislative drafting that always requires knowledge of existing provisions in the relevant legislation and case law on the subject matter in

\footnotetext{
192 Regina v. Chambers [2008] EWCA (Crim) 2467 [65]-[68].

193 See Jamar, supra note 108 ("Scholars studying comparative law would find their work significantly easier to do."). On how poor global access to legal information hampers international legal research, see Bayly, supra note 23 (discussing a Canadian human rights intern's frustration with the unavailability of Malian legal information online in 2015).

${ }^{194}$ See Poulin, supra note 17 (discussing how the Internet facilitates free dissemination of national laws thereby making them available for a global audience).

195 See Bayly, supra note 23.
} 
question. ${ }^{196}$ This is essential for ensuring harmony between legislation being drafted and existing legislation to avoid unintended consequences such as consequential or implied amendments when a provision in a new legislation conflicts with a previous legislation. Such a problem requires resolution by the court through statutory interpretation as to whether a current provision supersedes a previous one on the same issue. ${ }^{197}$

Fourth, adequate public access to legal information enhances compliance with the tenets of democracy. One such tenet is public participation in the affairs of the government. Its examples include involvement in the legislative process through awareness of every piece of proposed legislation (bills) and discussion of government policies and programs. ${ }^{198}$ Based on the fact that legal information is part of public information, the unhindered right of people to access it boosts accountability and transparency in governance by eliminating the culture of secrecy. Adequate public access to legal information is essential to the cause of justice and the rule of law. ${ }^{199}$ Graham and Peruginelli rightly consider it to be one of the "necessary conditions for a working democracy." 200 In fact, legal information is so important to human society that the Montreal Declaration states that "[p]ublic legal information from all countries and international institutions is part of the common heritage of humanity." 201

Fifth, it provides authentic texts of official ${ }^{202}$ legal information for reuse or republishing by all those interested in doing so-commercial publishers, authors, and not-for-profit organizations. This contributes to socio-economic development through employment and the economic activities involved. It also enhances the dissemination of vital information necessary for peace and order and operation of the rule of law. ${ }^{203}$

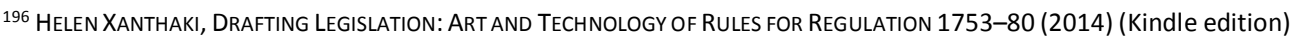
("Amongst the very first considerations of the drafter is to ensure that they understand clearly and fully the current legal position on the topic of the requested legislation.").

${ }^{197}$ Ron Beal, The Art of Statutory Construction: Texas Style, 64 BAYLOR L. REV. 339, 414-15 (2012).

198 Perritt, supra note 20, at 899 (discussing how public participation in the decision-making process of the government promotes good governance).

199 Id. See also Montreal Declaration, supra note 42 ("Maximising access to this information promotes justice and the rule of law.").

200 Graham Greenleaf \& Ginevra Peruginelli, A Comprehensive Free Access Legal Information System for Europe 2 (University of New South Wales Law Research Paper No. 2012-9, 2012), http://ssrn.com/abstract=2012956; see also Poulin, supra note 17 (discussing the importance of free access to legal information to the rule of law and democracy).

${ }^{201}$ Montreal Declaration, supra note 42.

202 See supra note 13 (providing a definition of authentic texts of legal information) \& note 14 (providing a definition of official texts of legal information).

${ }^{203}$ See Perritt, supra note 20, at 899; Montreal Declaration, supra note 42. 


\section{To Give Global Legal Effect to the Numerous Principles, Declarations, and Statements on Free Public Access to Legal Information}

Over the years, several international and regional bodies and nongovernmental organizations have expressed their common aspirations for a new regime of public access to legal information in numerous principles, declarations, and statements. They include the Montreal Declaration on Free Access to Law (2002), ${ }^{204}$ The Hague Conference Guiding Principles to be Considered in Developing a Future Instrument (2008), ${ }^{205}$ Law.Gov Principles and Declaration (2010), ${ }^{206}$ and the Calgary Statement on Free Access to Legal Information (2011). ${ }^{207}$ They contain the philosophy behind-and standards for-public access to legal information. They also identify and declare the right to it. But the contribution of these principles, declarations, and statements to public access to legal information is limited because they are not binding.

It is therefore necessary to give global legal effect to the noble aspirations and objectives contained in these principles, declarations, and statements whose formulation involved consultations, deliberations, research, and huge amounts of human and financial resources expended in organizing the international and regional fora where they were made and adopted. The best way to achieve these aspirations and objectives is to harmonize the principles, declarations, and statements as part of the contents of a binding international human rights instrument on the right of public access to legal information, as I advocate below.

\section{To Promote the Rule of Law}

The human society is governed by law, without which it will degenerate to the primordial state of survival of the fittest, laisser-faire, anarchy, and chaos that will threaten human civilization. That explains the importance of the operation of the rule of law that was made prominent by Albert Venn Dicey through his analysis in his book, Introduction to the Study of the Law of the Constitution. ${ }^{208}$ There are unresolved controversies on the exact definition of the rule of law, but its three components in Lord Bingham's definition-equality before

\footnotetext{
${ }^{204}$ Montreal Declaration, supra note 42.

205 The Hague Conference Guiding Principles, supra note 78.

${ }^{206}$ Law.Gov Principles, supra note 79.

${ }^{207}$ Calgary Statement, supra note 80.

208 A. V. Dicey, Introduction to the Study of the LaW of the Constitution 171-92 (3rd ed. 1889), https://ia802701.us.archive.org/11/items/introductiontos04dicegoog/introductiontos04dicegoog.pdf (last visited July 9, 2017).
} 
the law, equal access to the law, and public promulgation and application of the law ${ }^{209}$-are settled and germane to this discussion. "Equality before the law" includes accountability to the law that includes the duty to obey the law. ${ }^{210}$ "Equal access to the law" encompasses equal access to justice through the courts and equal access to the sources of law or legal information. "Public promulgation of law" comprises its transparent enactment process and dissemination for public knowledge through its widest possible publication and publicity. The following definition by the United Nations clearly highlights these sacred requirements:

The "rule of law" ... refers to a principle of governance in which all persons, institutions and entities, public and private, including the State itself, are accountable to laws that are publicly promulgated, equally enforced and independently adjudicated, and which are consistent with international human rights norms and standards .... ${ }^{211}$

The right to know the law - as discussed in Part C above-emanates from the duty to obey the law, both of which necessitate the duty of every government and every IGO that makes law to publicly promulgate and publish it to provide adequate access to its full texts in different formats. The right of public access to legal information is therefore rooted in the rule of law. It is therefore necessary to give this right the greatest possible protection throughout the world, as part of the promotion of the rule of law that every society needs. It is only the formal universal recognition of the right of public access to legal information as a human right that can provide such protection, as discussed in Section D.II.2 above.

\section{The Proposed UN Convention on the Right of Public Access to Legal Information}

In this Section, I discuss my proposal for a new UN Convention as the ultimate possible solution to the problem of inadequate access to authentic and official legal information and its attendant injustice and difficulties in national and international legal research.

\section{Advocacy for a New UN Convention on the Right of Public Access to Legal Information}

The UN Declaration on Human Rights Defenders provides for the right of everyone to advocate the creation of new human rights to meet any future need for the universal

\footnotetext{
${ }^{209}$ D. BROOKE, Q\&A JURISPRUDENCE 40 (6th ed. 2013).

${ }^{210}$ DICEY, supra note 208 , at 190.

211 U.N. Secretary General, The Rule of Law and Transitional Justice in Conflict and Post-Conflict Societies, UN Doc. S/2004/616 (Aug. 23, 2004), at 4; The Rule of Law, StANFORD ENCYCLOPEDIA OF PHILOSOPHy (June 22, 2016), http://plato.stanford.edu/entries/rule-of-law/ (last visited July 6, 2017).
} 
protection of new categories of inalienable rights whenever such protection is justified. Its Article 7 provides: "Everyone has the right, individually and in association with others, to develop and discuss new human rights ideas and principles and to advocate their acceptance."

Pursuant to the said Article 7 of the UN Declaration on Human Rights Defenders, I therefore advocate the formal universal recognition of the right of public access to legal information as a distinct human right to protect all categories of legal information referred to in my definition of the "right of public access to legal information" in Part C above. The quoted statement from the United Nations in Section D.II.4 above reveals the importance of such formal recognition to the protection of human rights. This proposal is based on the eight reasons discussed in the immediately preceding Section D.II above. They are as follows: To fill the normative gaps associated with its existing derivative status; to provide the human rights framework for its promotion, protection, and actualization; it should be recognized as a human right based on the precedent of the Aarhus Convention; and it has the basic characteristics of human rights. Additionally, its formal universal recognition as a human right is necessary to remedy the injustice from the application of the ignorantia juris doctrine where the law is inaccessible; to realize the numerous benefits derivable from adequate public access to legal information; to give global legal effect to the numerous principles, declarations, and statements on free public access to legal information; and to promote the rule of law.

Further, I recommend the drafting, adoption, and implementation of a new UN Convention on the Right of Public Access to Legal Information ("the proposed UN Convention") as the international human rights framework for its global promotion, protection, and actualization. The proposed UN Convention should protect all categories of legal information, as stated in Section D.I.2 above.

Similar to the CRPD that did not create a new right but "express[ed] existing rights in a manner that addresses the needs and situation of persons with disabilities," ${ }^{212}$ the proposed UN Convention incorporates all aspects of the existing right of public access to legal information and formulates them in a comprehensive manner that will provide the requisite universal standards. This is the most potent way to strengthen the existing right of public access to legal information, as discussed in the immediately preceding Section D.II above. The contents of the proposed UN Convention are outlined below.

212 UNITED NATIONS, supra note 143 , at 2. 


\section{The Contents of the Proposed UN Convention on the Right of Public Access to Legal Information}

This is an outline of the contents of the proposed UN Convention on the Right of Public Access to Legal Information. These contents are necessary for its drafting. They incorporate recommendations in The Hague Guiding Principles to be Considered in Developing a Future Instrument (2008) ${ }^{213}$ (The Hague Conference Guiding Principles). They are "[p]rinciples developed by the experts which met on 19-21 October 2008 at the invitation of the Permanent Bureau of The Hague Conference on Private International Law as part of its feasibility study on the 'access to foreign law' project." ${ }^{214}$ Although these Principles were specifically developed for global access to legal information, they contain some of the core principles for good access at all levels. The 18 Principles in the 18 paragraphs of The Hague Conference Guiding Principles are quoted in Sections D.III.2.1 to D.III.2.9 below. I have incorporated these 18 Principles into my discussion and notes that appear under them, and they clothe my suggestion of the contents with additional international legitimacy. The contents discussed in Sections D.III.2.10 to D.III.2.15 are not mentioned in The Hague Conference Guiding Principles, but they are also core principles that the proposed UN Convention should contain.

These contents reflect the essential principles that will promote, protect, and actualize the right of public access to legal information globally, but they are not exhaustive. Details of the more specialized technical standards based on the latest technology for the production, publishing, management, and application of legal information are to be determined by a consortium of the leading experts in legal informatics who are familiar with modern legal information systems.

\subsection{Free Access}

"1. State Parties shall ensure that their legal materials, in particular legislation, court and administrative tribunal decisions and international agreements, are available for free access in an electronic form by any persons, including those in foreign jurisdictions."

"2. State Parties are also encouraged to make available for free access relevant historical materials, including preparatory work and legislation that has been amended or repealed, as well as relevant explanatory materials." ${ }^{215}$

\footnotetext{
${ }^{213}$ The Hague Conference Guiding Principles, supra note 78. See the Appendix to this Article for a Microsoft Word version of The Hague Guiding Principles that is available online as a PDF document in the public domain.

${ }^{214}$ Id.

${ }^{215}$ Id. See Principles 1 \& 2.
} 
The provision of free and adequate public access to legal information for the benefit of every person, irrespective of their profession and other circumstances, is a primary legal and moral duty of every government and every organization with legislative and judicial functions. The concept of free public access to legal information derives from the right of every person to know the law. That right emanates from the legal principle that ignorance of the law is no excuse because every person has a duty to know, and is therefore presumed to know, ${ }^{216}$ the law. $^{217}$

The State should provide free access to both physical and electronic versions of legal information through public libraries ${ }^{218}$ and websites containing comprehensive and up-todate legal information databases for use by the whole world. ${ }^{219}$ I agree with McMahon that the cost of providing free access to legal information is one of the inherent costs of democracy. ${ }^{220}$ Online legal information resources are now so indispensable to the provision of free public access to up-to-date primary and secondary sources of law that the Durham Statement on Open Access to Legal Scholarship "urge[d] every U.S. law school to commit to ending print publication of its journals and to making definitive versions of journals and other scholarship produced at the school immediately available upon publication in stable, open, digital formats, rather than in print.".221

\footnotetext{
${ }^{216}$ See INGRAM, supra note 62.

${ }^{217}$ See supra Section C; Section D.II.5 (discussing a remedy for the injustice from the ignorantia juris doctrine).

${ }^{218}$ See Harvey, supra note 106, at 107-08 (discussing the New Zealand Depository Library Scheme); see generally Tammy R. Pettinato, Legal Information, the Informed Citizen, and the FDLP: The Role of Academic Law Librarians in Promoting Democracy, 99 L. LIBR. J. 695 (2007) (discussing the U.S. Federal Depository Library Program). See also Mitee, supra note 15 , at 56-58.

${ }^{219}$ See Greenleaf (2008), supra note 17 (discussing the role played by legal information institutes in the evolution of the concept of free public access to online legal information). For my discussions on innovative ways of enhancing public access to available official online legal information, see Leesi Ebenezer Mitee, Enhancing Public Access to Legal Information: A Proposal for a New Official Legal Information Generic Top-Level Domain, 22(2) EJOCLI (2017), http://webjcli.org/article/view/562 \& http://ejocli.org/; Leesi Ebenezer Mitee, Towards Enhanced Public Access to Legal Information: A Proposal for Official Networked One-Stop Legal Information Websites, 8(2) or (3) EJLT (2017), http://ejlt.org/ (forthcoming).

220 McMahon, supra note 28.

${ }^{221}$ Durham Statement, supra note 18. On the indispensability of online legal information resources, see McMahon, supra note 28; Arnold-Moore (2003), supra note 84. For the need for authentication of digital legal information, see sources cited supra note 13; see infra Section D.III.2.3 (discussing the integrity and authoritativeness of legal information).
} 
Adequate public access to court decisions, ${ }^{222}$ subject to anonymization requirements for purposes of the right to privacy and data protection in appropriate cases, ${ }^{223}$ is essential. Access to case law appears to be the most neglected aspect of public access to legal information. This accounts for the monopolistic commercialization of law reports. It is absurd that many courts rely on commercial law reports of their own judgments. Perhaps there are millions of unreported cases worldwide, whose inaccessibility adversely affects public access to judicial decisions at all levels of the court systems in various countries. ${ }^{224}$

Every judgment of a legitimate court or tribunal, no matter its status in the judicial hierarchy, is entitled to publication. This is useful for various purposes, for example, as a permanent evidence of its existence and for research by the judiciary, legal practitioners, academics, students, law enforcement agencies, etc. Further, free access to judicial decisions ensures transparency that promotes justice because it helps every person to know the facts of a case, the judge, and the basis for the decision, from which the judge's impartiality can be ascertained. ${ }^{225}$ This is particularly necessary in common-law jurisdictions that apply the doctrine of judicial precedents. The following statement encapsulates the importance of adequate public access to court decisions: "Access to case law is of fundamental importance for the Rule of Law: it facilitates the scrutiny of justice, contributes to the transparency of the judiciary and informs the public about the continuous development of the law." 226

Someone may argue that free public access to up-to-date and comprehensive legal information in public libraries and online-for the benefit of the whole world-could lead to increase in self-representation in court and the resultant decrease in the overall quality of legal representation. Even if the argument turns out to be valid-but it may not be-it

\footnotetext{
${ }^{222}$ See Org. for Security \& Co-operation in Eur., Access to Court Decisions: Legal Analysis of Relevant International and National Provisions 3 3 13 (Sept. 2008), http://www.right2info.org/resources/publications/publications/OSCE_AnalysisAccesstoCourtDecisions17092008. pdf. As emphasized throughout this Article, online access to authentic judicial decisions is indispensable; on the need for authentication of digital legal information, see sources cited supra note 13 (authentication) and see infra Section D.III.2.3 (discussing the integrity and authoritativeness of legal information).

223 See generally Koen Versmissen, OSCE Mission to Skopje, Expert Report on Access to Court Decisions and Protection of Personal Data in the former Yugoslav Republic of Macedonia (Oct. 2011); Krisztina Kovács, European Commission for Democracy Through Law (Venice Commission), Report: The Anonymity Requirement in Publishing Court Decisions (July 1, 2011), http://www.venice.coe.int/webforms/documents/?pdf=CDL-JU(2011)010-e.

${ }^{224}$ See, e.g., Unreported Judgments Online, LEXISNEXIS, http://www.lexisnexis.com.au/en-AU/Products/unreportedjudgments-online.page (last visited July 6, 2017) (claiming that LexisNexis has a database of over 237,200 Australian judicial decisions that it updates three times daily).

${ }^{225}$ See Poulin, supra note 17 (discussing how free access to legal information strengthens national judicial systems).

${ }^{226}$ ECLI Background, BLDG ON ECLI, http://bo-ecli.eu/ecli/background (last visited July 6, 2017).
} 
cannot not be used to limit public access to legal information nor deny self-representation, because they are human rights that are inalienable. ${ }^{227}$

\subsection{Reproducing and Re-use}

"3. State Parties are encouraged to permit and facilitate the reproduction and re-use of legal materials, as referred to in paragraphs 1 and 2, by other bodies, in particular for the purpose of securing free public access to the materials, and to remove any impediments to such reproduction and re-use."228

There should be no copyright in the texts of legal information. Information protected by privacy laws is an exemption to the right to reproduce such content. Copyright in the texts of legal information is a barrier to its free dissemination by those who wish to do so; they include authors, not-for-profit organizations, and commercial publishers. Although the provision of public access to legal information is a primary duty of every government and every organization with legislative and judicial functions, interested parties that publish it enhance its dissemination and add value to the original texts. Copyright usually subsists in any value-added unique arrangements, translations, adaptations, and annotations, ${ }^{229}$ but it should not extend those produced by any government or IGO. ${ }^{230}$

Article 2(4) of the Berne Convention for the Protection of Literary and Artistic Works ${ }^{231}$ (Berne Convention) states: "It shall be a matter for legislation in the countries of the Union to determine the protection to be granted to official texts of a legislative, administrative and legal nature, and to official translations of such texts." Leaving the issue of copyright to the discretion of each country is an obstacle to the right of public access to legal information. ${ }^{232}$

227 See supra Section D.II.1 (discussing the right of public access to legal information as a human right with a derivative status). Self-representation is a human right under international and regional human rights instruments such as Article 14(3)(d) of the International Covenant on Civil and Political Rights and Article 6(3)(c) of the European Convention on Human Rights.

${ }^{228}$ The Hague Conference Guiding Principles, supra note 78. See Principle 3.

${ }^{229}$ Ford, supra note 87 , at 550.

${ }^{230}$ See sources cited supra notes 26-27 and accompanying text (discussing the assertion of copyright in official annotations in legislation in the United States).

${ }^{231}$ Berne Convention for the Protection of Literary and Artistic Works, July 24, 1971, 1161 U.N.T.S. 3 [hereinafter Berne Convention].

232 See Johan Pas \& Bruno De Vuyst, Re-establishing the Balance between the Public and the Private Sector: Regulating Public Sector Information Commercialization in Europe, JILT (2004), http://www2.warwick.ac.uk/fac/soc/law/elj/jilt/2004_2/pasanddevuyst/ (stating that the Berne Convention may be used by European countries that are Parties to it to impose some copyright restriction on legal information in contradistinction to the U.S. position under its copyright legislation that excludes copyright from works of the federal government. 
There is therefore the urgent need to amend the said Article 2(4) to expressly prohibit copyright protection in the texts of legal information so that there is no option for the imposition of copyright restrictions by member States. ${ }^{233}$

\subsection{Integrity and Authoritativeness}

"4. State Parties are encouraged to make available authoritative versions of their legal materials provided in electronic form."

"5. State Parties are encouraged to take all reasonable measures available to them to ensure that authoritative legal materials can be reproduced or re-used by other bodies with clear indications of their origins and integrity (authoritativeness)." ${ }^{234}$

The vulnerability of cyberspace to hacking and fraudulent or accidental alteration of resources has now made it necessary to preserve the integrity of digital information with authentication technologies, such as digital signatures and public key infrastructure (PKI). ${ }^{235}$ Authentication is necessary for investing a document with official status. ${ }^{236}$ Legal information with official status has evidentiary value for all legal purposes, including admissibility in courts of law. Therefore, authentication of legal information should be considered a mandatory feature to be added to existing resources on all official legal information websites and as an integral part of the process of creating new ones. ${ }^{237}$ The U.S. Govinfo website is an excellent example of the use of authentication technologies for official documents, especially the application of digital signatures to PDF files. ${ }^{238}$ An example of such

\footnotetext{
${ }^{233}$ See Mitee, supra note 15, at, 65-68 (stating that "the Berne Convention for the Protection of Literary and Artistic Works has contributed negatively to access to government-held information including legislation by leaving the issue of copyright in such information at the discretion of each State party").

${ }^{234}$ The Hague Conference Guiding Principles, supra note 78. See Principles 4 \& 5.

235 Authentication, U.S. Gov'T PRINTING OFFICE (Oct. 13, 2005) https://www.gpo.gov/pdfs/authentication/authenticationwhitepaperfinal.pdf; Claire M. Germain, Worldwide Access to Foreign Law: International and National Developments Toward Digital Authentication, 9 COMP. L. J. PACIFIC 185 (2013), https://ssrn.com/abstract=2676279. See also THE IALL INTERNATIONAL HANDBOOK OF LEGAL INFORMATION MANAGEMENT 14 (RICHARD A. DANNER \& JULES WINTERTON eds., 2016).

${ }^{236}$ State-By-State Report on Authentication of Online Legal Resources: Executive Summary, AM. Ass'N OF LAW LIBRARIES (Mar. 2007), http://www.aallnet.org/Documents/Government-

Relations/authen_rprt/executivesummaryreport.pdf.

237 See IFLA Statement on Government Provision of Public Legal Information in the Digital Age, INT'L FED'N LIBRARY Associations AND INSTITUTIONS (Dec. 15, 2016), https://www.ifla.org/publications/node/11064.

${ }^{238}$ See About Us, Govinfo, https://www.govinfo.gov/about (last visited July 6, 2017).
} 
digitally authenticated legislation is the Promoting Women in Entrepreneurship Act, 42 U.S.C. $1861 .^{239}$

"6. State Parties are encouraged to remove obstacles to the admissibility of these materials in their courts." 240

Paragraph 6 of The Hague Conference Guiding Principles states that "State Parties are encouraged to remove obstacles to the admissibility of these materials in their courts." This Principle should be reviewed because it may be risky to have multiple sources of the same official legal information with evidentiary value that makes such legal information admissible in courts. The State should provide authenticated legal information on its official website for all users, but it may be prudent that no authentic legal information on any third-party website should also have official status with evidentiary value. It is usually better to err on the side of caution, especially because of the limitless technological possibilities that in the future may jeopardize the integrity of even authenticated digital information. The magnitude of such a problem will increase with multiple sources. The evidentiary presumption of the accuracy and validity of information from an official source ${ }^{241}$ supports this suggestion.

\subsection{Preservation}

"7. State Parties are encouraged to ensure long-term preservation and accessibility of their legal materials referred to in paragraphs 1 and 2 above." ${ }^{242}$

Preservation of legal information-irrespective of the media in which it is published-is crucial to ensuring that it remains intact for both present and future generations. For example, the world-famous Magna Carta that was issued by King John of England on 15 June 1215 -more than 800 years ago-on vellum, ${ }^{243}$ a durable writing material made from goatskin, is still available today. ${ }^{244}$ Britain started printing record copies of both public and

\footnotetext{
239 Public Law 115-6-Feb. 28, 2017, Govinfo, https://www.govinfo.gov/content/pkg/PLAW-115publ6/pdf/PLAW115publ6.pdf (last visited July 6, 2017).

${ }^{240}$ The Hague Conference Guiding Principles, supra note 78. See Principle 6.

${ }^{241}$ People v. Melchor, 237 Cal. App. 2 d 685 (1965); Greenleaf (2013), supra note 94, at 7.

242 The Hague Conference Guiding Principles, supra note 78. See Principle 7.

${ }^{243}$ See Why is the UK Still Printing its Laws on Vellum?, BBC (Feb. 15, 2016), http://www.bbc.com/news/magazine35569281.

244 See Doris Mary Stenton, Magna Carta, ENCYCLOPAEDIA BRITANNICA (2017), https://www.britannica.com/topic/Magna-Carta.
} 
private Acts on vellum in 1849 but the practice ended, for private Acts in $1956^{245}$ and public Acts in 2017, because of the huge costs involved. ${ }^{246}$ The UK government has now decided to use high-quality, durable archival paper instead of vellum. ${ }^{247}$

Digital information has peculiar preservation problems that are associated with the inability of information technology systems to function properly. For example, it will be difficult or even impossible for many people to use information on floppy disks (diskettes) these days because modern computers no longer have any provision for them. Sandborn categorized these problems as functional obsolescence, such as hardware obsolescence and software obsolescence; technological obsolescence, such as termination of support, license, and maintenance; and logistical obsolescence that affects different aspects of the functioning and performance of the digital media. ${ }^{248}$ ISO 16363 is the recommended International Standard on best practices for determining the trustworthiness of digital repositories, ${ }^{249}$ including the preservation of online legal information, as practiced by the U.S. Govinfo. ${ }^{250}$

\subsection{Open Formats, Metadata and Knowledge-Based Systems}

"8. State Parties are encouraged to make their legal materials available in open and re-usable formats and with such metadata as available."

"9. States Parties are encouraged to cooperate in the development of common standards for metadata applicable to legal materials, particularly those intended to enable and encourage interchange." 251

\footnotetext{
245 Vellum: Printing Record Copies of Public Acts, PARLIAMENT.UK, (May 11, 2016), http://researchbriefings.parliament.uk/ResearchBriefing/Summary/CBP-7451.

${ }^{246}$ Christopher Hope, Anger as MPs Bow to Peers' Pressure and End 500-Year Old Tradition of Printing New Laws on Vellum, TELEGRAPH (Mar. 21, 2017), http://www.telegraph.co.uk/news/2017/03/21/anger-mps-bow-peerspressure-end-500-year-old-tradition-printing/.

247 Id.

248 Peter Sandborn, Software Obsolescence-Complicating the Part and Technology Obsolescence Management Problem, 30(4) IEEE TRANSACTIONS ON COMPONENTS AND PACKAgING TECHNOLOGIES 886 (2007), http://www.enme.umd.edu/ESCML/Papers/IEEE_SoftwareObs.pdf. See also Richard S. Whitt, "Through A Glass, Darkly" Technical, Policy, and Financial Actions to Avert the Coming Digital Dark Ages, 33 SANTA CLARA HIGH TECH. L.J. 117 (2017), http://digitalcommons.law.scu.edu/chtlj/vol33/iss2/1.

249 16363: Space Data and Information Transfer Systems-Audit and Certification of Trustworthy Digital Repositories, INT'L ORGANIZATION FOR STANDARDIZATION, https://www.iso.org/obp/ui/\#iso:std:iso:16363:ed-1:v1:en (last visited May 29, 2017).

${ }^{250}$ About Us, Govinfo, https://www.govinfo.gov/about (last visited July 6, 2017).

${ }^{251}$ The Hague Conference Guiding Principles, supra note 78. See Principles 8 \& 9.
} 
It is not enough just to make legal information available online, although doing so is indispensable to every free public access to legal information project, as discussed in Section D.III.2.1 above. It is also necessary to publish legal information in different digital formats that meet the diverse needs of its users and other requirements. ${ }^{252}$ For instance, Portable Document Format (PDF) has become the default format for authenticated digital legal information that has official status with evidentiary value for all legal purposes. ${ }^{253}$ Publishing official legal information in PDF makes it possible to have identical official electronic and print versions. But PDF has its disadvantages. For example, its fixed format makes it impossible to flow and adapt to different display screen sizes. In addition, it is difficult to reuse PDF documents because their conversion to other formats usually affects the accuracy of the converted document. That is the reason legal information should, in addition to its PDF version, be published in open formats, for example, eXtensible Markup Language (XML) that is versatile and easy to re-use with its integrity intact. ${ }^{254}$

"10. Where State Parties provide knowledge-based systems assisting in the application or interpretation of their legal materials, they are encouraged to make such systems available for free public access, reproducing and re-use." 255

There should be no copyright in annotations and other value-added features produced or owned by any government or IGO because they are meant to help the people to understand the texts of the law, and they are also public information produced with taxpayers' money. ${ }^{256}$

\subsection{Protection of Personal Data}

"11. Online publication of court and administrative tribunal decisions and related material should be in accordance with protection of personal data laws of the State of origin. Where

\footnotetext{
252 Edward S. Dove, Reflections on the Concept of Open Data, 12(2) SCRIPTED 154, 157-59 (2015), https://scripted.org/wp-content/uploads/2015/12/Dove.pdf.

${ }^{253}$ Authentication, Govinfo, https://www.govinfo.gov/about/authentication (last visited July 9, 2017).

254 See Legislative XML for the Semantic Web: Principles, Models, Standards for Document Management (Giovanni SARTOR, Monica PALMIRANI, ENRICO FRANCESCONI, \& MARIA ANGELA BIASIOTTI eds., 2011); Legislative Documents in XML at the United States House of Representatives, U.S. HOUSE OF REPRESENTATIVES (Sept. 2, 2016), https://xml.house.gov/; Uses of XML, IBM, https://www.ibm.com/support/knowledgecenter/ssw_i5_54/rzamj/rzamjintrouses.htm (last visited July 6, 2017).

255 The Hague Conference Guiding Principles, supra note 78 (Principle 10).

${ }^{256}$ See sources cited supra notes 26-27 and accompanying text (discussing the assertion of copyright in official annotations in legislation in the United States).
} 
names of parties to decisions need to be protected, the texts of such decisions and related material can be anonymized in order to make them available for free access." ${ }^{257}$

Public access to court decisions should be subject to anonymization best practices for the protection of the right to privacy and data protection in appropriate cases, as discussed in Section D.III.2.1 above.

\subsection{Citations}

"12. State Parties are encouraged to adopt neutral methods of citation of their legal materials, including methods that are medium-neutral, provider-neutral and internationally consistent." 258

The Neutral Citation Standard for Case Law (the neutral citation)-developed by the Canadian Citation Committee that was set up in 1998-was approved in 1999 for use in all courts through Canada. ${ }^{259}$ It was in response to the ever-increasing importance of electronic legal information databases, especially on websites. It is a case identifier that that has the following features: It uses numbered paragraphs instead of page numbers; the court assigns its sequential numbers; and reference is made to the court that decided the case instead of a law report. For example, in the neutral-cited Regina v. Chambers [2008] EWCA Crim 2467 [55] that features prominently in this Article, the citation elements are as follows: names of the parties, year of decision, abbreviated name of the court, case number, and paragraph number. "EWCA Crim" means England and Wales Court of Appeal (Criminal Division).

Vidler-Smith \& Prebble rightly state that the importance of neutral citation-also referred to as "medium-neutral citation", "vendor-neutral citation", and "provider-neutral citation" - "lies not in small stylistic variations, but in the allocation of unique sequential numbers to judgments and in the paragraph numbering of judgments." ${ }^{260}$ It is usually preferable to have a uniform permanent reference system that the neutral citation guarantees. Neutral citation has good prospects of its global acceptance, although some countries, such as the United States, are still reluctant to adopt it. ${ }^{261}$ The system may have the unique public-access advantage of spurring every court to publish its own decisions online. And that is the right thing to do.

\footnotetext{
${ }^{257}$ The Hague Conference Guiding Principles, supra note 78. See Principle 11.

258 Id. See Principle 12.

259 Frédéric Pelletier, the neutral Citation Standard for Case law: A Summary, https://lexum.com/cccccr/neutr/docs/NeutralCitation_Summary_2010.doc (last visited July 9, 2017).

260 Catherine Vidler-Smith \& John Prebble, The Emergence of Neutral Citation, 4(1) OUCL 121, 125 (2004), https://papers.ssrn.com/sol3/papers.cfm?abstract_id=1604994.

${ }^{261}$ Id. at $125-28$.
} 


\subsection{Translations}

"13. State Parties are encouraged, where possible, to provide translations of their legislation and other materials, in other languages."

"14. Where State Parties do provide such translations, they are encouraged to allow them to be reproduced or re-used by other parties, particularly for free public access."

"15. State Parties are encouraged to develop multi-lingual access capacities and to co-operate in the development of such capacities." ${ }^{262}$

Translation of at least all the extant laws in a jurisdiction into all official languages of that jurisdiction is essential to the success of public access to legal information, ${ }^{263}$ as practiced by the European Union, ${ }^{264}$ for instance. It enables the people who use those languages to know the laws regulating their conduct and activities, to justify the operation of the doctrine of presumption of knowledge of the law. ${ }^{265}$ In Lambert v. California, the Court noted "the [great] evil... when the law is written in print too fine to read or in a language foreign to the community. ${ }^{\prime 266}$ It is simply unjust to require people to know and obey laws written in any language they do not understand. Linguistic rights are human rights that empower people groups to use their languages, ${ }^{267}$ and they constitute a major component of cultural rights. ${ }^{268}$

\footnotetext{
262 The Hague Conference Guiding Principles, supra note 78. See Principles 13, 14, \& 15.

${ }^{263}$ See Mitee, supra note 15, at 84-87.

${ }^{264}$ EU laws are translated into the 24 Official EU languages, see Translation: Official EU Languages, EUROPEAN UNION, http://ec.europa.eu/dgs/translation/translating/officiallanguages/index_en.htm (last visited July 6, 2017) (listing all the languages and the importance of the translation of E.U. laws).

265 See INGRAM, supra note 62.

${ }^{266}$ Lambert v. California, 225 U.S. 355 (1957), https://supreme.justia.com/cases/federal/us/355/225/case.html.

${ }^{267}$ ICCPR, art. 27; G.A. Res. 61/295, arts. 2-3, 5, 8, 13-16, UN Declaration on the Rights of Indigenous Peoples (Sept. 13, 2007). See Universal Declaration on Linguistic Rights, art. 18 (June 9, 1996), http://www.unesco.org/cpp/uk/declarations/linguistic.pdf. This Declaration was made by institutions and nongovernmental organizations in Barcelona.

${ }^{268}$ See International Covenant on Economic, Social and Cultural Rights arts. 1, 3, 6 \& 15, Dec. 16, 1966, 993 U.N.T.S. 3 [hereinafter ICESCR]. Language as a means of communication is intricately interwoven with culture. See CLAIRE KRAMSCH, LANGUAGE AND CULTURE 3 (1998).
} 


\subsection{Support and Co-operation}

"16. State Parties and re-publishers of their legal materials are encouraged to make those legal materials more accessible through various means of interoperability and networking."

"17. State Parties are encouraged to assist in sustaining those organisations that fulfil the above objectives and to assist other State Parties in fulfilling their obligations."

“18. State Parties are encouraged to co-operate in fulfilling these obligations." ${ }^{269}$

The achievement of free public access to legal information globally requires the support and cooperation of State parties and all those involved in all the necessary processes. The reason is that State parties and IGOs are the burden bearers that have the legal and moral duty to provide adequate and free public access to legal information, as discussed in Section C.IV above.

\subsection{Drafting in Plain Language}

The requirements of best practices in legal drafting ensure that every type of legal information is intelligible and thereby effective. They include the use of clear, precise, and unambiguous language in legal documents so that the documents are properly understood. ${ }^{270}$ The use of plain language has now become the standard practice in legal drafting. ${ }^{271}$ Fischer rightly defines plain English as "familiar, succinct, understandable English, generally written in the active voice without legalese and unnecessary jargon or foreign phrases." 272 It is no longer fashionable to use the so-called "lawyerly language"273 that is characterized by archaic legalese and long, winding sentences that the Eighth Circuit

\footnotetext{
${ }^{269}$ The Hague Conference Guiding Principles, supra note 78. See Principles 16, 17, \& 18.

${ }^{270}$ See EUR-LEX, supra note 82, at 7-8; XANTHAKI, supra note 196, at loc. 3408-4018.

${ }^{271}$ For the meaning and use of plain language, see generally Anthony Watson-Brown, Defining "Plain English" as an Aid to Legal Drafting, 30 STATUTE L. REV. 85 (2009).

272 Judith D. Fischer, Why George Orwell's Ideas about Language Still Matter for Lawyers, 68 MoNT. L. REV. 129, 132 (2007). See also Rabeea Assy, InJustice in Person: The Right to Self-Representation 73-74 (2015) (discussing how the use of plain English makes the law accessible and intelligible to non-lawyers, thereby facilitating their right to represent themselves in judicial proceedings).

273 See David Ball, David Ball on Damages: The Essential Update-A Plaintiff's Attorney's Guide for Personal Injury AND WRONGFUL DEATH CASES 294-95 (2005).
} 
deprecated as "nefarious and nonsensical legalese". ${ }^{274}$ Similarly, legal Latinisms ${ }^{275}$ and difficult-to-understand vocabulary are no longer fashionable.

\subsection{Alternate Formats for Equal Access by Persons with Disabilities}

It is necessary to produce alternate formats of legal information to meet the needs of persons with various forms of disability, whose rights are protected by the CRPD. ${ }^{276}$ The use of several types of assistive technology makes it possible to provide such special access. For example, Braille helps the blind to read texts of legal information, such as the Braille publications on South African laws on domestic violence and children. ${ }^{277}$ Printed texts should be large enough to meet the needs of users with poor eyesight. ${ }^{278}$ Audio and video formats are necessary for those who need to hear the texts or see them demonstrated. For instance, the UDHR has a recorded audio version, read by Anna Eleanor Roosevelt who chaired the UN committee that drafted the Declaration. ${ }^{279}$ UDHR also has a video version in sign language. ${ }^{280}$ The Australian Government legislation website uses BrowseAloud assistive technology to enhance accessibility through text-to-speech and screen magnification for persons with literacy problems, cognitive disabilities, and visual impairment. ${ }^{281}$

\footnotetext{
274 Jefferson Co. v. Halverson, 276 F.3d 389, 393 (8th Cir. 2002). See also Fischer, supra note 272, at 142.

275 Fischer, supra note 272, at 142-43. See also Julia C. Mead, Legal Latinisms, Dead or Alive?, N.Y. TIMES (Jan. 26,
} 2003), http://www.nytimes.com/2003/01/26/nyregion/legal-latinisms-dead-or-alive.html.

276 Convention on the Rights of Persons with Disabilities, Dec. 13, 2006, 2515 U.N.T.S. 3 [hereinafter CRPD]. See Mitee, supra note 15, at 87-90.

277 See Yolisa Tswanya, Laws in Braille will Help Blind Understand their Rights, PrESSREADER (July 19, 2012), https://www.pressreader.com/south-africa/cape-argus/20120719/281736971571697.

${ }^{278}$ See Lambert, 355 U.S. at 355 (1957) (noting the evil in any law "written in print too fine to read" or in a language that members of the community do not understand).

279 See Universal Declaration of Human Rights, UDHR, https://udhr.audio/UDHR_Video.asp?lng=eng (last visited July 6, 2017) (audio version of UDHR); Universal Declaration of Human Rights: History of the Document, UNITED NATIONS, http://www.un.org/en/sections/universal-declaration/history-document/ (last visited July 6, 2017) (stating that Anna Eleanor Roosevelt, the wife of U.S. President Franklin D. Roosevelt, chaired the committee that drafted the UDHR).

280 See, e.g., UDHR in Sign Languages, OfFICE OF THE UN HIGH COMM'R FOR HUM. RTS. (last visited July 6, 2017), http://www.ohchr.org/EN/UDHR/Pages/UDHRinsignlanguages.aspx (featuring videos of the Universal Declaration of Human Rights in British and Spanish sign languages); New Zealand Sign Language Content Offers Deaf Community Better Access to Legal Information, N.Z. L. Soc'y (May 12, 2016), https://www.lawsociety.org.nz/news-andcommunications/latest-news/news/new-zealand-sign-language-content-offers-deaf-community-better-access-tolegal-information.

${ }^{281}$ See sources cited supra note 71 (discussing the use of assistive technology for access to legal information by persons with disabilities). 


\subsection{Public Access to the Customary Law of Indigenous Communities}

It is essential to provide adequate public access to the customary law of indigenous communities. Customary law forms a plural legal system in many countries with indigenous communities. Most of these countries were once colonized by other countries and empires. There are at least sixty-four countries that have plural legal systems which comprise a mixture of customary law and one or more other legal systems - civil law, common law, and religious law. ${ }^{282}$ Liberia $^{283}$ and Ethiopia, ${ }^{284}$ for example, were not colonized, in the strict sense of colonization, but they also have plural legal systems. Liberia has a system of common law and customary law while that of Ethiopia is civil law and customary law. ${ }^{285}$

Customary law in its native oral state is inaccessible because many people are not sure of what it is, in terms of definite rules and their validity. That is the reason for the judicial requirement that the existence of the unwritten rules of customary law must be proved to the satisfaction of the court. For example, section 18(1) \& (2) of the Nigerian Evidence Act 2011 states:

(1) Where a custom cannot be established as one judicially noticed, it shall be proved as a fact.

(2) Where the existence or the nature of a custom applicable to a given case is in issue, there may be given in evidence the opinions of persons would be likely to know of its existence in accordance with section 73.

The highest quantum of proof is sometimes required to establish the existence of a custom. For instance, eleven witnesses were called to prove the existence of a rule of custom "beyond any reasonable doubt" in the South African case of Van Breda v. Jacobs. ${ }^{286}$ The unascertained and inaccessible nature of oral customary law caused such a huge waste of time and resources just to prove the existence of the custom in question. Such proof of oral

\footnotetext{
${ }^{282}$ Customary Law Systems and Mixed Systems with a Customary Law Tradition, JURIGLOBE-WORLD LEGAL SYSTEMS, http://www.juriglobe.ca/eng/sys-juri/class-poli/droit-coutumier.php (last visited July 6, 2017).

${ }^{283}$ See Walter C. Soderlund, Liberia, 1990: ECOMOG I, "Operation Liberty," UNOMIL in HUMANITARIAN CRISES AND INTERVENTION: REASSESSING THE IMPACT OF MASS MEDIA 21 (Walter C. Soderlund et al. eds., 2008).

284 See Lovise Aalen, The Politics of Ethnicity in Ethiopia: Actors, PoWer and Mobilisation Under Ethnic Federalism 87 (2011).

${ }^{285}$ See JURIGLOBE-WORLD LEGAL SYSTEMS, supra note 282.

${ }^{286}$ Van Breda v. Jacobs, 1921 (AD) 330, https://www.coursehero.com/file/21226446/VAN-BREDA-AND-OTHERS-vJACOBS-1921-AD-330/. See J. C. Bekker \& I. A. van der Merwe, Proof and Ascertainment of Customary Law, 26(1) SOUTHERN AFRICAN PUB. L. 115, 120 (2011), http://repository.up.ac.za/handle/2263/18455.
} 
customary law that depends on the memory and veracity of witnesses, the unnecessary costs and delays involved, and its susceptibility to corruption have adverse implications for justice and the rule of law, as I argue in my work, Huricompatisation: The Concept of Human Rights-Compliant Public Access to the Customary Law of Indigenous Communities. ${ }^{287}$

My above-mentioned work is a useful guide on the principles for the legal framework for adequate public access to the customary law of indigenous communities, which is significant because customary law is the most inaccessible type of law. First, access to legal information requires that the texts and effects of laws are both discoverable and ascertainable, as discussed in Part $\mathrm{C}$ above. Therefore, the valid and binding customs and practices that constitute customary law should be compiled by the responsible government and published in an appropriate permanent written form-but not codified-to make customary law accessible and ascertainable. Unlike codification that enacts customary as legislation, the proper ascertainment approach should be such that can preserve the adaptive nature of customary law as a living law that is always evolving and promote the human rights of the indigenous communities. Second, such published customary law should be comprehensive, translated into the language of the community, authoritative, and binding on the people to whom it is applicable. Third, apart from codification whose flaws appear to be obvious, the other methods of ascertainment of customary law-judicial ascertainment that I refer to as judicialization, restatement, and self-statement-are also flawed because they do not provide adequate public access to the customary law of indigenous communities. Fourth, none of the four existing methods of ascertainment of customary law is human rightscompliant. There is therefore the need for a new ascertainment approach that provides adequate public access to the customary law of indigenous communities and is also human rights-compliant, which is a concept that I formulate with the acronym huricompatisation in my said work.

\subsection{Public Awareness of Legal Information}

An effective legal information public awareness program (LIPAP) ${ }^{288}$ is essential for helping people to know the existing laws and participate in the process of making new laws. The reason is that the philosophy behind the right of public access to legal information is to acquire the best possible knowledge of the law to guide one's conduct and activities. A sustainable LIPAP must use all available means of mass communication, for example,

287 Leesi Ebenezer Mitee, Huricompatisation: The Concept of Human Rights-Compliant Public Access to the Customary Law of Indigenous Communities (forthcoming 2017). For the flaws of codification as a method of ascertainment of the customary law of indigenous communities, see David Weisbrot, Customary Law, 1 ABORIGINAL L. BULL. 1, 3-4 (1981-1998); Joan Vincent, Contours of Change: Agrarian Law in Colonial Uganda, 1895-1962, in History AND POWER IN THE StUdY Of LAW: NEW DiRECTIONS IN LEgAL ANTHRopology 166 (June Starr \& Jane F. Collier eds., 1989); Jelle J. P. Wouters, Land Tax, Reservation for Women and Customary Law in Nagaland 52 (9) ECONOMIC \& Poltical WeEKLY 20, 23 (2017).

288 The term with its abbreviation is my coinage. 
television, radio, and official government newspapers specifically designated for LIPAP; social media, including Facebook and Twitter; and electronic messaging alert services, such as email and text messages. Real-time broadcast of all legislative businesses and other law-making activities of every government and every IGO is imperative. ${ }^{289}$ Indigenous communities should also use their homegrown means of information dissemination to create public awareness of laws, such as the use of town criers. ${ }^{290}$

\subsection{Access to the Internet}

State parties to the Convention shall have the obligation to formulate and implement policies and programs that will create the enabling environment for free ${ }^{291}$ or affordable and adequate Internet connectivity in terms of speed, reliability, and unlimited data usage. ${ }^{292}$ । discussed the importance of online legal information in Section D.III.2.1 above. Even where there is an excellent legal information online database, if people are unable to access it due to the prohibitive cost of Internet access, data usage limits, and unreliable and frustratingly low-speed Internet connectivity, then the database becomes technically inaccessible.

Internet access is so indispensable to the realization of the human right of freedom of expression and the press-which encompasses the right of access to public informationand other rights, that Estonia enacted a law in 2000 to recognize it as a human right. ${ }^{293}$ Subsequently, the Constitutional Council of France (2009) and the Constitutional Court of Costa Rica (2010) also declared it a human right. ${ }^{294}$ In 2011, the UN Special Rapporteur on the Promotion and Protection of the Right to Freedom of Opinion and Expression concluded that denying Internet access by cutting off its users amounted to a violation of Article 19,

\footnotetext{
${ }^{289}$ See Mitee, supra note 15, at 56-62 (discussing legislation awareness programme).

290 Mary Omogor Ifukor, Channels of Information Acquisition and Dissemination Among Rural Dwellers, 5(10) IJLIS 306, 307 (2013), http://www.academicjournals.org/journal/IJLIS/article-full-text-pdf/494E19F40088 (lasted visited July 8, 2017); Chimezie P. Uzuegbu \& Moses M. Naga, Information Communication to Rural Cassava Farmers in Nigeria: A Pilot Study, 9(2) JAIST (2016), http://jaistonline.org/vol9no2_2016.html (lasted visited July 8, 2017); Henry Kam Kah, Civil Society, Socio-Economic Development and Nation-Building In West Africa, 7(4) AAJOSS (2016), http://www.onlineresearchjournals.com/aajoss/art/220.pdf (lasted visited July 8, 2017).

${ }^{291}$ Free Internet connectivity should be available in public depository libraries that stock government-held information which includes legal information.

292 See Arnold-Moore (2003), supra note 84.

${ }^{293}$ Frank La Rue (Special Rapporteur on the Promotion and Protection of the Right to Freedom of Opinion and Expression), Rep. of the Special Rapporteur on the Promotion and Protection of the Right to Freedom of Opinion and Expression, U.N. Doc. A/HRC/17/27, at para. 65 (May 16, 2011) [hereinafter Frank La Rue (2011)].

${ }^{294} / d$.
} 
paragraph 3, of the ICCPR. ${ }^{295}$ This development underscores the importance of the appropriate global policy on Internet access to the right of public access to legal information.

\title{
2.15 No Liability Under Inaccessible Law
}

No person shall be held liable for violating the provision of any law that was not adequately published to the extent that the person, in their particular circumstances, should reasonably be expected to know the exact contents of that law. The courts have upheld this principle in some jurisdictions, including Canada and the Philippines. ${ }^{296}$

Because there is usually at least one necessary exception to every general legal principle, the proposed UN Convention should state that this defense of ignorance of the law on the ground of inaccessibility shall not apply to any act that a reasonable person is expected to know is illegal or unlawful even without knowing the law that specifically declared it illegal or unlawful. Examples of such acts are certain heinous, morally despicable, and dangerous offenses like murder, torture, armed robbery, rape, kidnapping, causing grievous bodily harm, and drunk driving. ${ }^{297}$

\footnotetext{
${ }^{295} / d$. at paras. 78-79. For a discussion on the human right of access to the Internet, see generally Stephen Tully, $A$ Human Right to Access the Internet? Problems and Prospects, 14 HUM. RTS. L. REV. 175 (2014).

${ }^{296}$ Tañada v. Tuvera, supra note 59 (“[B]efore the public is bound by its contents, especially its penal provisions, a law, regulation or circular must first be published and the people officially and specially informed of said contents and its penalties."); Corporation de l'École Polytechnique v. Canada, 2004 FCA 127, para. 39 (CanLII):
}

\begin{abstract}
Invincible mistake of law, accepted by the courts and Parliament, refers to mistakes which it is impossible to avoid because it is impossible for the person charged to know the law, either because it has not been promulgated or because it was not published in a satisfactory way so that its existence and contents could be known.
\end{abstract}

(emphasis added).

"[lg]norance of the law due to its non-publication must be a credible defence." See CARLSON ANYANGWE, CRIMINAL LaW: The General PART 207 (2015). Frans Rumpff, the Chief Justice of South Africa, delivered a revolutionary unanimous judgment in 1977 that abolished the general application of the doctrine of ignorance of the law is no excuse in relation to mens rea in criminal offenses. See State v. De Blom 1977 (3) SA 513 (A) at 529 H (S. Afr.).

297 See Stephen P. Garvey, Authority, Ignorance, and the Guilty Mind, 67 SMU L. REV. 545, 556 (2014) (conceding that ignorance of the law should not be an excuse with regard to mala in se offenses); see also Cottone, supra note 173 , at 143 (asserting the relative ease of public awareness of the unlawfulness of mala in se offenses in contrast with regulatory offenses: "For example, one would be hard-pressed to find a person that never heard of someone going to prison for murder or robbery-the illegality of these acts has been hammered into our collective consciousness."). The age-old judicial distinction between mala prohibita (evil-because-prohibited) and mala in se (naturally-evil) offenses is established in criminal law. See generally Mark S. Davis, Crimes Mala in Se: An EquityBased Definition, 17 CRIM. JUST. Pol'Y Rev. 270 (2006); State v. Anderson, 5 P.3d 1247, 141 Wash. 2d 357 (2000); Note, The Distinction between "Mala Prohibita" and "Mala in se" in Criminal Law 30 Colum. L. Rev. 74 (1930). The distinction, despite its imperfection, is necessary for the attainment of justice in special circumstances to prevent 
The provision of Article 15(2) of the ICCPR on ex post facto criminal law is relevant to this proposed exception. It states: "Nothing in this article shall prejudice the trial and punishment of any person for any act or omission which, at the time when it was committed, was criminal according to the general principles of law recognized by the community of nations." As discussed in Section D.II.5 above, an inaccessible law is analogous to an expost facto law because the law is unknowable in both situations. Therefore, the said Article 15(2) justifies the proposed exception to the defense of inaccessible law. It should be emphasized that this necessary exception does not, in any manner whatsoever, diminish the legal and moral duty of any duty bearer to provide free access to comprehensive and up-to-date legal information, irrespective of its subject matter, as clearly advocated in this Article. The exception only aims to ensure that the defense is not abused by criminals.

Overall, the justice that this defense of inaccessible law strives to secure far outweighs any consequence that may emanate from its imperfection. After all, there is no perfect situation in any human institution, practice, or system. This provision for the defense of inaccessible law promises to spur all responsible governments and IGOs to provide free and adequate public access to their official and authentic legal information because they would want their laws to be enforceable and effective. This is the direct remedy to the injustice caused by the strict application of the ignorantia juris doctrine even when the law is inaccessible and therefore unknowable.

The proposed UN Convention will provide the human rights framework for the universal application of this essential principle that is upheld by the courts in some jurisdictions mentioned above and supported by Article 15(2) of the ICCPR. Perhaps, under the new dispensation, the new counterbalancing universal doctrine may well be "ignorance of inaccessible law is an excuse."

\section{E. Conclusion}

This Article has examined the desirability of the universal recognition of the right of public access to legal information as a human right and therefore as part of a legal framework for improving global access to legal information. Specifically, it sought to find out if there is an existing right of public access to legal information; and if the right is found to exist, to determine whether it qualifies for universal recognition as a human right, which would strengthen it to improve national and global access to legal information.

The right of public access to legal information is a legal right that exists under the general right of access to public information because every government holds such information in

avoidance of liability based on my proposed human-right defense of inaccessible and therefore unknowable law. The application of this distinction here is based on accessibility of the law, not on criminal intent-mens rea. 
trust for the people who are the rightful owners. ${ }^{298}$ Although FOIAs may be used to access legal information, ${ }^{299}$ as it is the case with other types of public information, it is inadequate because it mainly provides limited reactive access on a piecemeal basis in response to a specific request instead of a permanent proactive access for the whole world at all time. The use of mandamus is also limited because it is a discretionary order. ${ }^{300}$ The right of public access to legal information also exists under the traditional requirement in obsolete statutes that laws should be published, which did not contemplate the use of modern technology. ${ }^{301}$ Contemporary statutory provisions have evolved in some jurisdictions to secure its modern existence, although they are still inadequate. ${ }^{302}$ Furthermore, it is also a human right with a derivative status from its parent human right of freedom of expression and the press under international and regional instruments, as well as national constitutions. ${ }^{303}$ In addition, its existence enjoys judicial recognition in some jurisdictions. ${ }^{304}$ These findings therefore satisfy objective (1) of this Article: "To find out if there is an existing right of public access to legal information."

Objective (2) of this Article states: "To determine whether the right of public access to legal information, if it is found to exist, qualifies for universal recognition as a human right, which will strengthen it to improve national and global access to legal information." Although the right of public access to legal information exists, it is largely ineffectual, as discussed in Parts $\mathrm{C}$ and $\mathrm{D}$ of this Article. The reason is that its global legal framework is inadequate and therefore unable to exert sufficient pressure on governments to provide free access to their comprehensive and up-to-date legal information. That is why adequate public access to legal information is not yet fully achieved even in the developed countries, and virtually nonexistent in some developing countries. ${ }^{305}$

The right of public access to legal information qualifies for universal recognition as a distinct human right to fill the normative gaps associated with its existing derivative status and to

\footnotetext{
${ }^{298}$ See supra Section C.I (discussing the existence of the right of public access to legal information under the general right of access to public or government-held information).

${ }^{299}$ See id.

${ }^{300}$ See supra Section C.V (discussing judicial recognition and enforcement of the existing right of public access to legal information).

${ }^{301}$ See supra Section C.II (discussing the traditional requirement of publication of legal information).

${ }^{302}$ See supra Section C.III (discussing the use of advanced technologies to enhance accessibility).

${ }^{303}$ See supra Section D.II.1 (discussing the normative gaps associated with the existing derivative status).

${ }^{304}$ See supra Section C.V (discussing judicial recognition and enforcement of the existing right of public access to legal information).

${ }^{305}$ See supra notes 21-23 and accompanying text (discussing the poor public access to legal information in Nigeria and Mali).
} 
provide the human rights framework for its promotion, protection, and actualization. The Aarhus Convention is a precedent that it is possible, and even desirable, to have Conventions on crucial aspects of public information that are not adequately protected, chief among which is legal information. Further, it has the basic characteristics of human rights and its formal human rights status will remedy the injustice from the application of the ignorantia juris doctrine where the law is inaccessible. In addition, its formal universal recognition will help to realize the numerous benefits derivable from adequate public access to legal information; give global legal effect to the numerous principles, declarations, and statements on free public access to legal information; and promote the rule of law.

The formal universal recognition of the right of public access to legal information under the framework of the UN Convention on the Right of Public Access to Legal Information that I propose in this Article is the legitimate and effectual mechanism to promote, protect, and actualize it globally. The United Nations, according to its statement quoted in Section D.II.4 above, recognizes the importance and significance of such formal recognition to the protection of human rights. Douglas-Scott recently extolled the potent force of human rights for justice and its attainment ${ }^{306}$ which is a major goal of the proposed UN Convention. The Convention will set the minimum global standards that constitute binding obligations ${ }^{307}$ on governments to provide adequate public access to their legal information. The obligations also extend to all organizations with legislative and judicial functions that are non-State actors. No such global standards exist under the present dispensation. As a human right, in addition to the UN monitoring and implementation mechanisms, it will become the most powerful tool to be used by civil society to put pressure on governments and the said nonState actors to meet their international obligations under the proposed UN Convention. Ordinary legal rights do not enjoy such exalted status and global protection as human rights. ${ }^{308}$ Therein lies the importance of the human rights framework for strengthening the right of public access to legal information to improve global access, which is the focus of this Article.

The contents of the proposed UN Convention outlined in this Article are useful because they highlight the essential principles necessary for drafting the Convention. In addition, because of the delays usually associated with the processes that culminate in the adoption and entering into force of any UN Convention, ${ }^{309}$ these contents also provide a useful guide on

\footnotetext{
${ }^{306}$ See Douglas-Scott, supra note 138.

${ }^{307}$ See Office of the UN High Comm'r for Hum. Rts., supra note 142, at 2-3.

${ }^{308}$ See supra Section D.II.2 (detailing the human rights framework for the right of public access to legal information).

${ }^{309}$ For instance, with regard to the CRPD, there was a period of about seven years between the setting up of its Ad Hoc Committee by the General Assembly in 2001 and when it entered into force on May 3, 2008. See Convention on the Rights of Persons with Disabilities: Why a Convention?, UNITED NATIONS (Apr. 21, 2016),
} 
the development and implementation of urgent interim national and regional policies and programs on the achievement of adequate public access to legal information. The best way to implement such interim policies and programs, pending the entering into force of the proposed UN Convention, is to enact them as laws on public access to legal information. In this way, there will be improvement in public access to legal information even before the proposed UN Convention enters into force to provide the definitive global legal framework for it. The provision of valuable input for policymakers is, of course, the natural use of any research that contains law reform proposals and is policy-relevant like this Article. ${ }^{310}$

The existing international human rights framework, declarations, constitutions, legislation, statements, principles, policies, and judicial decisions have not solved the global problem of inadequate-and in some cases extremely poor-public access to legal information. ${ }^{311}$ Yet every willing government can afford the provision of adequate access to its legal information. ${ }^{312}$ Therefore, only a consequential departure from the status quo, an innovative solution, should be expected to produce the positive change that is needed urgently. That is exactly the revolutionary intervention through the human rights framework that this Article advocates. The formal universal recognition of the right of public access to legal information as a human right under the framework of the proposed UN Convention, promises to improve significantly global access to legal information. Among its numerous benefits, it will promote widespread knowledge of the law and facilitate global legal research on an unprecedented scale. It will also advance the cause of justice by helping lawyers and the courts to know the current position of the law to avoid wrong decisions, as the English case of Regina v. Chambers ${ }^{313}$ revealed; strengthen participatory democracy; and enhance the rule of law. Particularly, it will remedy the chronic injustice caused by the strict application of the ignorantia juris doctrine even where the law is inaccessible and therefore

\footnotetext{
http://www.un.org/disabilities/convention/questions.shtml\#five (providing the background to the Convention that was adopted on Dec. 13, 2006).

310 See generally Tony Kingdon, The Relevance of Research to Policy Formulation: An Australian Perspective, 88 AdDICTION 61S (Supplement s1, Jan., 1993); Alexander C. Wagenaar, Research Affects Public Policy: The Case of the Legal Drinking Age in the United States, 88 AdDICTION 75S (Supplement s1, Jan., 1993); Amanda Wolf, Research Strategies for Policy Relevance, 23 Soc. PoL'Y J.N.Z. (2004); UNCTAD Virtual Inst. on Trade and Dev., Research-Based Policy Making: Bridging the Gap between Researchers and Policy Makers (Recommendations for Researchers and Policy Makers Arising from the joint UNCTAD-WTO-ITC Workshop on Trade Policy Analysis, Geneva, Sept. 11-15, 2006), https://vi.unctad.org/tda/papers/tradedata/tdarecs.PDF.

${ }^{311}$ See, e.g., supra notes 21-23 (discussing the poor public access to legal information in Nigeria and Mali).

${ }^{312}$ See supra Part B (discussing the lack of political will hinders public access to legal information).

${ }^{313}$ Regina v. Chambers [2008] EWCA (Crim) 2467 (revealing that previous decisions of the England and Wales Court of Appeal over a period of seven years were based on a repealed regulation that neither the Court nor the lawyers that appeared before it knew of).
} 
unknowable, in the different circumstances exemplified by Rex v. Bailey ${ }^{314}$ and United States $v$. Casson. ${ }^{315}$ In the new dispensation under the proposed UN Convention, the new counterbalancing universal doctrine may well be "ignorance of inaccessible law is an excuse." ${ }^{316}$

\footnotetext{
${ }^{314}$ Rex v. Bailey (1800) 168 Eng. Rep. 651 (Eng.).

315 United States v. Casson, 434 F.2d 415 (D.C. Cir. 1970).

${ }^{316}$ See supra Section D.III.2.15 (discussing the proposal that there should be no liability under any inaccessible law).
} 


\section{Appendix: Guiding Principles to be Considered in Developing a Future Instrument ${ }^{317}$}

\section{Free access}

1. State Parties shall ensure that their legal materials, in particular legislation, court and administrative tribunal decisions and international agreements, are available for free access in an electronic form by any persons, including those in foreign jurisdictions.

2. State Parties are also encouraged to make available for free access relevant historical materials, including preparatory work and legislation that has been amended or repealed, as well as relevant explanatory materials.

Reproducing and re-use

3. State Parties are encouraged to permit and facilitate the reproduction and re-use of legal materials, as referred to in paragraphs 1 and 2, by other bodies, in particular for the purpose of securing free public access to the materials, and to remove any impediments to such reproduction and re-use.

\section{Integrity and authoritativeness}

4. State Parties are encouraged to make available authoritative versions of their legal materials provided in electronic form.

5. State Parties are encouraged to take all reasonable measures available to them to ensure that authoritative legal materials can be reproduced or re-used by other bodies with clear indications of their origins and integrity (authoritativeness).

6. State Parties are encouraged to remove obstacles to the admissibility of these materials in their courts.

\section{Preservation}

7. State Parties are encouraged to ensure long-term preservation and accessibility of their legal materials referred to in paragraphs 1 and 2 above.

\footnotetext{
317 The Hague Conference Guiding Principles to be Considered in Developing a Future Instrument (2008), an annexure to ACCESS to ForeIGN LAW IN CIVIL AND COMmERCIAL MATTERS: CONCLUSIONS AND RECOMMENDATIONS, EUR. COMm'N, https://assets.hcch.net/upload/foreignlaw_concl_e.pdf(last visited July 6, 2017). These are principles developed by the experts which met on Oct. 19-21, 2008 at the invitation of the Permanent Bureau of the Hague Conference on Private International Law as part of its feasibility study on the "access to foreign law" project.
} 
Open formats, metadata and knowledge-based systems

8. State Parties are encouraged to make their legal materials available in open and re-usable formats and with such metadata as available.

9. States Parties are encouraged to cooperate in the development of common standards for metadata applicable to legal materials, particularly those intended to enable and encourage interchange.

10. Where State Parties provide knowledge-based systems assisting in the application or interpretation of their legal materials, they are encouraged to make such systems available for free public access, reproducing and re-use.

\section{Protection of personal data}

11. Online publication of court and administrative tribunal decisions and related material should be in accordance with protection of personal data laws of the State of origin. Where names of parties to decisions need to be protected, the texts of such decisions and related material can be anonymized in order to make them available for free access.

\section{Citations}

12. State Parties are encouraged to adopt neutral methods of citation of their legal materials, including methods that are medium-neutral, provider-neutral and internationally consistent.

\section{Translations}

13. State Parties are encouraged, where possible, to provide translations of their legislation and other materials, in other languages.

14. Where State Parties do provide such translations, they are encouraged to allow them to be reproduced or re-used by other parties, particularly for free public access.

15. State Parties are encouraged to develop multi-lingual access capacities and to co-operate in the development of such capacities.

\section{Support and co-operation}

16. State Parties and re-publishers of their legal materials are encouraged to make those legal materials more accessible through various means of interoperability and networking. 
17. State Parties are encouraged to assist in sustaining those organizations that fulfill the above objectives and to assist other State Parties in fulfilling their obligations.

18. State Parties are encouraged to cooperate in fulfilling these obligations. 